\title{
Proanthocyanidins and Flavan-3-ols in the Prevention and Treatment of Periodontitis-Immunomodulatory Effects, Animal and Clinical Studies
}

\author{
Izabela Nawrot-Hadzik $^{1}{ }^{\mathbb{D}}$, Adam Matkowski ${ }^{1, * \mathbb{D}}$, Paweł Kubasiewicz-Ross ${ }^{2}$ and Jakub Hadzik $^{2} \mathbb{D}$ \\ 1 Department of Pharmaceutical Biology and Botany, Wroclaw Medical University, 50556 Wroclaw, Poland; \\ izabela.nawrot-hadzik@umed.wroc.pl \\ 2 Department of Dental Surgery, Wroclaw Medical University, 50425 Wroclaw, Poland; \\ pawel.kubasiewicz-ross@umed.wroc.pl (P.K.-R.); jakub.hadzik@umed.wroc.pl (J.H.) \\ * Correspondence: bbsekret@umed.wroc.pl
}

Citation: Nawrot-Hadzik, I.;

Matkowski, A.; Kubasiewicz-Ross, P.; Hadzik, J. Proanthocyanidins and Flavan-3-ols in the Prevention and Treatment of PeriodontitisImmunomodulatory Effects, Animal and Clinical Studies. Nutrients 2021, 13, 239. https://doi.org/10.3390/ nu13010239

Received: 25 November 2020

Accepted: 11 January 2021

Published: 15 January 2021

Publisher's Note: MDPI stays neutral with regard to jurisdictional claims in published maps and institutional affiliations.

Copyright: (c) 2021 by the authors. Licensee MDPI, Basel, Switzerland. This article is an open access article distributed under the terms and conditions of the Creative Commons Attribution (CC BY) license (https:// creativecommons.org/licenses/by/ $4.0 /)$.

\begin{abstract}
This paper continues the systematic review on proanthocyanidins and flavan-3-ols in the prevention and treatment of periodontal disease and covers the immunomodulatory effects, and animal- and clinical studies, while the other part discussed the direct antibacterial properties. Inflammation as a major response of the periodontal tissues attacked by pathogenic microbes can significantly exacerbate the condition. However, the bidirectional activity of phytochemicals that simultaneously inhibit bacterial proliferation and proinflammatory signaling can provide a substantial alleviation of both cause and symptoms. The modulatory effects on various aspects of inflammatory and overall immune response are covered, including confirmed and postulated mechanisms of action, structure activity relationships and molecular targets. Further, the clinical relevance of flavan-3-ols and available outcomes from clinical studies is analyzed and discussed. Among the numerous natural sources of flavan-3-ols and proanthocyanidins the most promising are, similarly to antibacterial properties, constituents of various foods, such as fruits of Vaccinium species, tea leaves, grape seeds, and tannin-rich medicinal herbs. Despite a vast amount of in vitro and cell-based evidence of immunomodulatory there are still only a few animal and clinical studies. Most of the reports, regardless of the used model, indicated the efficiency of these phytochemicals from cranberries and other Vaccinium species and tea extracts (green or black). Other sources such as grape seeds and traditional medicinal plants, were seldom. In conclusion, the potential of flavan-3-ols and their derivatives in prevention and alleviation of periodontal disease is remarkable but clinical evidence is urgently needed for issuing credible dietary recommendation and complementary treatments.
\end{abstract}

Keywords: condensed tannins; proanthocyanidins; flavan-3-ols; periodontitis; gingivitis; gum disease; cranberry; Camellia sinensis; polyphenols; immunomodulatory; natural compounds; natural substances

\section{Introduction}

In the previous paper, we demonstrated that both free flavan-3-ols and oligomeric proanthocyanidins are very promising constituents for combating various bacteria involved in periodontitis pathogenesis [1]. Here, using the same systematic approach, we have selected and discussed the recent data on anti-inflammatory and immunomodulating activities of these compounds, including in vivo models and clinical studies.

According to the latest concept of periodontitis etiopathology, the development of the disease requires the co-existence of dental plaque that accumulates on the teeth surface and the patient's immune-inflammatory response [2]. Periodontal bacteria cause the mobilization of innate immune response (e.g., large phagocytes like macrophages, antigenpresenting dendritic cells (DCs), natural killer (NK) cells and neutrocytes) as well adaptive immunity mechanisms ( $\mathrm{T}$ cells and B cells) that leads to the release of pro-inflammatory 
cytokines including interferon-gamma (IFN $\gamma$ ), interleukin-17 (IL-17), tumor necrosis factoralpha (TNF- $\alpha$ ), interleukin-1 and 6 (IL-1 and IL-6) and enzymes including in particular collagenases like matrix metalloproteinases (MMPs) [3] (Figure 1). By the inflammatory response the body protects itself against bacteria and their invasion inside the deeper tissues (such as bone). However, if the inflammatory process persists and is poorly regulated by the host, it can cause the most troublesome detrimental changes in periodontium tissue form and function such as periodontal pockets, attachment loss, gingival recessions, tooth mobility, tooth migration, and tooth loss [4]. Literature provides the data about anti-inflammatory and antioxidant effects of polyphenols which include flavan-3-ols and proanthocyanidins, drawing conclusions that they can be beneficial in the prevention and can be useful as a disease-controlling factor of a series of chronic diseases including diabetes, obesity, neurodegeneration, cancers, and cardiovascular diseases [5]. Our review focused on the activity the highly potent compounds among polyphenols in relation to periodontitis—a disease closely related to the inflammatory diseases mentioned above [2].

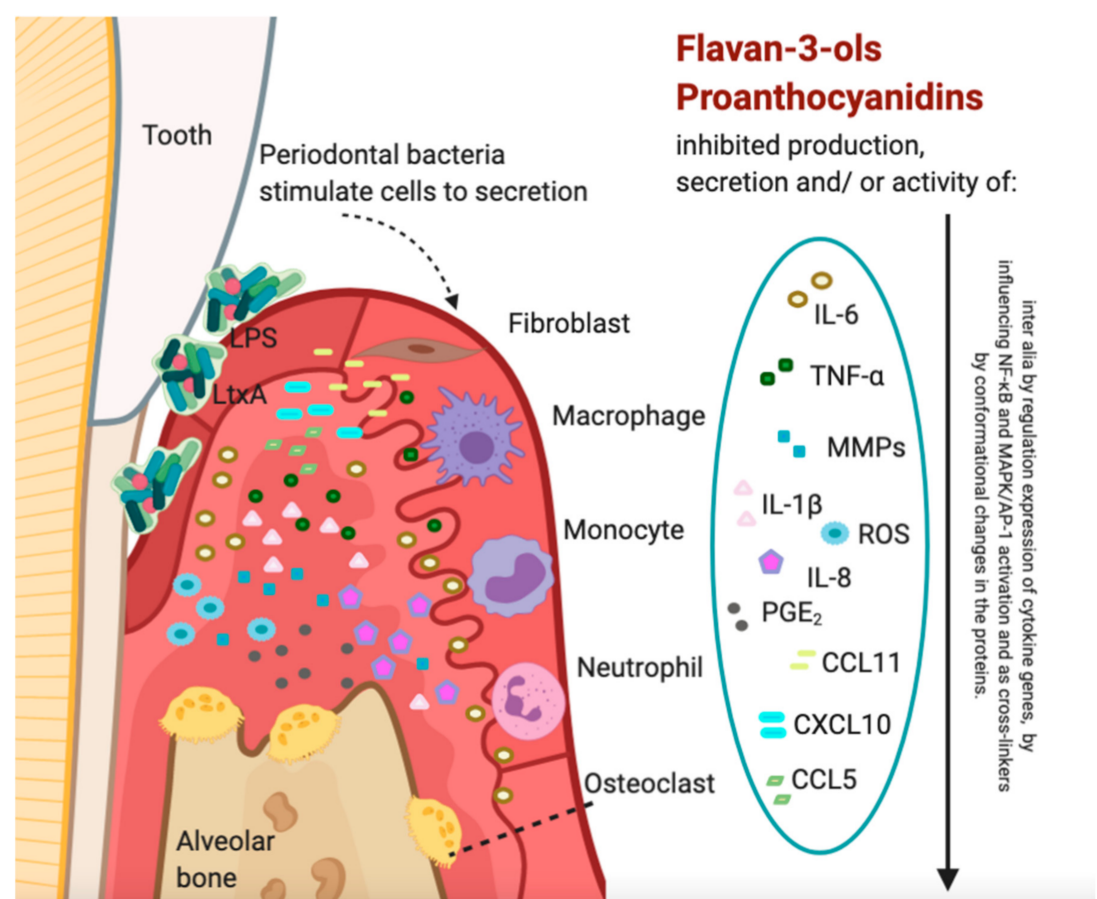

Figure 1. Schematic picture illustrating immunomodulatory activities of flavan-3-ols and proanthocyanidins in periodontitis. Some of the more important cytokines are shown in the figure. The figure was created using BioRender.com. Abbreviations shown in the figure: IL, interleukin; TNF- $\alpha$, tumor necrosis factor $\alpha$; MMP, matrix metalloproteinases; $\mathrm{ROS}$, reactive oxygen species; $\mathrm{PGE}_{2}$, prostaglandin $\mathrm{E}_{2} ; \mathrm{CCL}, \mathrm{C}-\mathrm{C}$ motif chemokine ligand; CXCL, C-X-C motif chemokine ligand; LPS, lipopolysaccharide; LtxA, Leukotoxin released by A. actinomycetemcomitans.

\section{Methods}

Search strategy, as well as inclusion, exclusion criteria, and data organization are described in our previous review [1], in which the antimicrobial activity of proanthocyanidins and flavan-3-ols in the prevention and treatment of periodontitis is discussed. In brief, a systematic review in compliance to PRISMA guidelines was performed. An electronic database search was conducted using PubMed, Web of Science and Scopus (accessed 23 December 2020).

The search terms included all combinations of the following key words: 'periodontitis' OR 'periodontal diseases' OR 'gingivitis' OR 'gingival diseases' AND 'proanthocyanidins' OR 'condensed tannins' OR 'flavan-3-ols' OR 'catechin' OR 'epicatechin' AND 'anti- 
bacterial' OR 'antiadhesive' OR 'anti-inflammatory', respectively. All titles with abstracts were imported into a citation manager program "Mendeley" (Elsevier, London, UK), and all duplicates were removed. References of imported articles were also screened for other relevant studies. Two investigators (N.-H.I. and K.-R.P.) independently reviewed the titles and abstracts of the imported references to determine whether they met the inclusion and exclusion criteria (Figure 2).

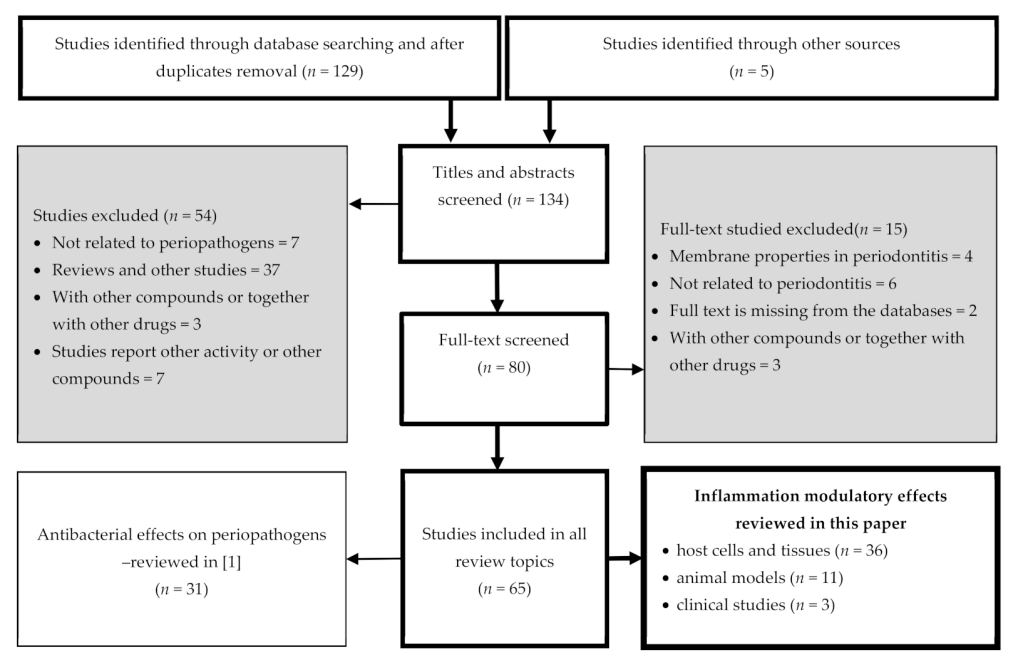

Figure 2. Flowchart of the article search strategy, exclusion criteria, study selection, and data management process. Of all 65 considered references, 50 are reviewed in this paper and 31 in [1], of which 16 references are included in both reviews.

Finally, 31 studies were reviewed in [1] (antibacterial effects) and 50 studies are included in the present paper (Figure 2).

\section{Immunomodulatory Effects of Proanthocyanidins or Flavan-3-ols on Host Cells and Tissues, In Vitro Studies}

\subsection{Influence on Matrix Metalloproteinases (MMPs)}

It was already proved that matrix metalloproteinases (MMPs) play a very important role in the process of periodontal connective tissue destruction. MMPs are a calciumdependent zinc-containing endopeptidases, responsible for the tissue remodeling and degradation of the extracellular matrix (ECM), including collagens, elastin, gelatin, matrix glycoproteins, and proteoglycan [6]. Major cell types that can be found in the periodontium, like fibroblasts, neutrophils, and macrophages, release these proteolytic enzymes [7]. These proteolytic enzymes are secreted as latent proenzymes (except membrane type (MT)-MMPs) and they must be later activated by tissue, plasma or bacterial proteinases extracellularly or at the cell surface. Under normal condition, MMPs play an important role in the healing of the wounds, the process of angiogenesis, and remodeling of the gingival tissue [8]. However, in periodontitis host cells are threatened by the periopathogens and their products such lipopolysaccharides (LPS) of Gram-negative bacteria. As a result, an increased production of MMPs can be observed that influences the degradation of periodontal ligaments, the loss of gingival collagen, and the resorption of alveolar bone, leading to destruction of periodontal tissues [9]. Increased activity of the enzymes-collagenases (matrix metalloproteinases 1 and 8) and gelatinases (matrix metalloproteinases 2 and 9) have been described in in the gingival crevicular fluid and in the inflamed gingival tissues of patients with periodontitis [10]. MMPs have the ability to activate and inactivate or even antagonize the biological functions of cytokines and chemokines. Through the influence on the cytokines and chemokines MMPs can regulate the inflammatory process by promoting or suppressing it. On the other hand, when the inflammatory cells are stimulated by 
cytokines and chemokines a production of MMPs may be induced [11]. Many studies proved that proanthocyanidins could inhibit activity of matrix metalloproteinases (Table 1).

Table 1. Immunomodulatory effects of proanthocyanidins (PAs) or flavan-3-ols on host cells and tissues-in vitro studies.

\begin{tabular}{|c|c|c|}
\hline $\begin{array}{l}\text { Active Com- } \\
\text { pound/Extract/Fraction }\end{array}$ & Cells/Tissues & Methods \\
\hline $\begin{array}{l}\text { Cranberry (Vaccinium } \\
\text { macrocarpon Ait.) } \\
\text { concentrate from } \\
\text { capsules (Uriach-Aquilea } \\
\text { OTC, Barcelona, Spain) } \\
\text { containing } 130 \mathrm{mg} \\
\text { A-Type } \\
\text { proanthocyanidins }\end{array}$ & $\begin{array}{l}\text { Human gingival } \\
\text { fibroblasts (HGF), } \\
\text { human osteosarcoma- } \\
\text { derived osteoblasts } \\
\text { (SAOS-2 cell line), } \\
\text { phorbol } \\
\text { myristate-acetate } \\
\text { (PMA)-induced } \\
\text { macrophages (from } \\
\text { THP-1 cells, a } \\
\text { monocytic leukemia } \\
\text { cell line). }\end{array}$ & $\begin{array}{l}\text { All the tested cells were } \\
\text { exposed for } 24 \text { h to different } \\
\text { cranberry concentrates ( } 25, \\
50 \text {, and } 100 \mu \mathrm{g} / \mathrm{mL} \text { ). After } \\
0,3 \text { and } 7 \text { days cell viability } \\
\text { assay was performed. } \\
\text { Interleukins: IL-8, IL-1 } \beta \text {, } \\
\text { IL-6, and IL-10 expression } \\
\text { of lipopolysaccharide (LPS } \\
\text { from Escherichia } \\
\text { coli)-stimulated } \\
\text { macrophages, and } \\
\text { macrophage polarization } \\
\text { were evaluated through } \\
\text { determination of live-cell } \\
\text { protease activity, } \\
\text { enzyme-linked } \\
\text { immunosorbent assay, and } \\
\text { immunofluorescence } \\
\text { staining } \\
\text { semi-quantification. }\end{array}$ \\
\hline
\end{tabular}

Unverified commercial proanthocyanidin (PA) purchased at ChemFace (Wuhan, China), with molecular weight $=$ 594.52 and untypical structure
Human periodontal ligament fibroblasts (HPDLFs).
HPDLFs used in the study were treated by the tumor necrosis factor-alpha (TNF- $\alpha), \mathrm{PA}$, or their combination. The mineralization markers and osteogenic differentiation markers and associated markers were detected by quantitative real-time polymerase chain reaction (qRT-PCR), alizarin red S staining, and alkaline phosphatase (ALP) activity assay.

\section{Results}

Authors, Year

Ref.
After $24 \mathrm{~h}$ exposure, the HGF,

SAOS-2, and macrophages

viability was not reduced by the cranberry concentrates;

Expression of proinflammatory

IL-8 and IL-6 was

downregulated by $50 \mu \mathrm{g} / \mathrm{mL}$

and $100 \mu \mathrm{g} / \mathrm{mL}$ PAs, but

expression of anti-inflammatory

IL-10 was upregulated at

$100 \mu \mathrm{g} / \mathrm{mL}$. No influence on

expression of IL-1 $\beta$ was seen.

Exposed LPS-stimulated

macrophages to PAs

significantly decreased M1

polarization and increased M2

polarization.
Galarraga-

Vinueza et al.,

2020

PA $(0.1,1,10 \mu \mathrm{g} / \mathrm{mL})$

significantly upregulated

expression of

proteins and ALP activity in

HPDLF compared with the

control group in the

non-inflammatory environment.

PA $(1 \mu \mathrm{g} / \mathrm{mL})$ has significantly

reversed the inhibition of

Huang et al. 2020

osteogenesis-related gene and

protein expression, ALP activity,

and mineralization caused by

TNF- $\alpha$. PA could regulate

osteogenesis of HPDLFs by

suppressing the NF- $\mathrm{kB}$

signaling pathway. osteogenesis-related genes and
THP-1 cells were

pre-treated with catechin

$(40 \mu \mathrm{M})$ and then infected with bacteria Porphyromonas gingivalis. The cytokine levels (IL- $1 \beta$ and TNF- $\alpha$ ) and relevant protein expression in THP-1 cells (e.g., pro-IL-1 $\beta$, NF-kB, toll-like receptor: TLR2, TLR4, and

Catechin

THP-1 cells mitogen-activated protein

kinases (MAPK) were measured using an ELISA

kits and Western blot analysis, respectively. Confocal laser scanning microscopy was used in this study to measure an apoptosis-associated speck-like protein pyroptosome formation. containing a caspase recruitment domain (ASC)
Catechin has inhibited $P$. gingivalis-induced the secretion of the TNF- $\alpha$ and IL- $1 \beta$ in tested THP-1 macrophages. Decreased production of IL- $1 \beta$ caused by catechin was due to its inhibition of pro-IL- $1 \beta$ expression via the downregulation of NF- $\kappa$ B, p38 MAPK, and TLR signaling. Moreover, the tested compound has inhibited the activation of inflammasomes induced by $P$. gingivalis but has not affected the growth of this bacteria.

.


Table 1. Cont.

\begin{tabular}{|c|c|c|c|c|c|}
\hline $\begin{array}{l}\text { Active Com- } \\
\text { pound/Extract/Fraction }\end{array}$ & Cells/Tissues & Methods & Results & Authors, Year & Ref. \\
\hline $\begin{array}{l}\text { Pelargonium sidoides DC } \\
\text { root extract (PSRE) and } \\
\text { proanthocyanidin } \\
\text { (prodelphinidins) fraction } \\
\text { from PSRE (PACN) }\end{array}$ & $\begin{array}{l}\text { Rat gingival } \\
\text { fibroblast cell culture; } \\
\text { Bone } \\
\text { marrow-derived } \\
\text { macrophages } \\
\text { (BMDM); Human } \\
\text { peripheral blood } \\
\text { mononuclear cells } \\
\text { (PBMCs). }\end{array}$ & $\begin{array}{l}\text { Cells (rat gingival } \\
\text { fibroblast, BMDM or } \\
\text { PBMCs) were treated with } \\
\text { PACN, PSRE, and LPS and } \\
\text { in case of BMDM, with } \\
\text { IFN } \gamma \text {. After treatments } \\
\text { medium was collected and } \\
\text { assayed for TNF- } \alpha \text {, IL-6, } \\
\text { IL- } 8 \text { and prostaglandin } E_{2} \\
\text { (PGE2) production using } \\
\text { TNF- } \alpha \text { mouse, IL- } 6 \text { human } \\
\text { IL- } 8 \text { rat and PGE2 rat; The } \\
\text { ability of PSRE, PACN to } \\
\text { modulate IL-1 } \beta, \text { TNF- } \alpha \text { and } \\
\text { iNOS expression in BMDM } \\
\text { and PBMCs was evaluated. } \\
\text { Expression of } \\
\text { proinflammatory cell } \\
\text { surface markers CD80 and } \\
\text { CD86 was analyzed by the } \\
\text { flow cytometry after } 24 \mathrm{~h} \\
\text { treatment LPS + } \\
\text { interferone- } \gamma \\
\text { (IFN } \gamma \text { )-activated BMDM } \\
\text { with PACN or PSRE. }\end{array}$ & $\begin{array}{l}\text { PSRE and PACN } \\
\text { ( } 50-100 \mu \mathrm{g} / \mathrm{mL} \text { ) has been } \\
\text { found to suppress the } \\
\text { LPS-induced IL- } 8 \text { and PGE } 2 \\
\text { release from the tested gingival } \\
\text { fibroblasts and IL- } 6 \text { release from } \\
\text { mononuclear leukocytes. PACN } \\
\text { has demonstrated a slightly } \\
\text { stronger IL- } 8 \text { and IL- } 6 \text { release } \\
\text { suppressing activity, and } \\
\text { significantly stronger PGE2 } \\
\text { release suppressing activity } \\
\text { than PSRE. PSRE and PACN } \\
\text { (100 } \mu \text { g /mL) has significantly } \\
\text { suppressed the mRNA } \\
\text { transcription of IL-1 } \beta, \text { iNOS, } \\
\text { and COX-2, but not TNF- } \alpha \text {. } \\
\text { PSRE and PACN (100 } \mu \text { g } / \mathrm{mL} \text { ) } \\
\text { reduced the level of CD } 80 \text { and } \\
\text { CD86-positive cells. PSRE } \\
\text { reduced by } 58 \% \text { and PACN by } \\
71 \% \text { the population of cells with } \\
\text { the exposed markers, compare } \\
\text { to LPS + IFN } \gamma \text {-activated BMDM } \\
\text { without the treatment. }\end{array}$ & $\begin{array}{l}\text { Jekabsone et al., } \\
2019\end{array}$ & [15] \\
\hline $\begin{array}{l}\text { Commercial green and } \\
\text { black tea extracts, } \\
\text { epigallocatechin-3- } \\
\text { gallate (EGCG), } \\
\text { theaflavin fraction } \\
\text { (mixture of theaflavin, } \\
\text { theaflavin-3-gallate, } \\
\text { theaflavin-3'-gallate, and } \\
\text { theaflavin-3, 3'-digallate) } \\
(80 \% \text { purity) }\end{array}$ & $\begin{array}{l}\text { U937 human } \\
\text { monocytes } \\
\text { differentiated to } \\
\text { macrophage-like } \\
\text { cells, gingival } \\
\text { keratinocyte cell line } \\
\text { B11, human oral } \\
\text { epithelial cell line } \\
\text { GMSM-K. }\end{array}$ & $\begin{array}{l}\text { Black and green tea extract, } \\
\text { EGCG, or theaflavins were } \\
\text { used to treat the } \\
\text { macrophage-like cells prior } \\
\text { to being stimulated with } \\
10 \mathrm{ng} / \mathrm{mL} \text { or } 100 \mathrm{ng} / \mathrm{mL} \text { of } \\
\text { recombinant human TNF- } \alpha \text {. } \\
\text { Intracellular and released } \\
\text { IL-1ß levels were } \\
\text { quantified using an ELISA } \\
\text { kit. Caspase-1 activation } \\
\text { and quantification as well } \\
\text { activation of the NF-kB } \\
\text { signaling pathway were } \\
\text { determined by commercial } \\
\text { assay. Gingival } \\
\text { keratinocytes were used to } \\
\text { study the influence of } \\
\text { tea-polyphenols on the } \\
\text { TNF- } \alpha \text {-induced disruption } \\
\text { of tight junction integrity } \\
\text { which was determined by } \\
\text { measuring TER } \\
\text { (transepithelial electrical } \\
\text { resistance). ELISA kit was } \\
\text { used to quantify IL- } 8 \\
\text { secretion by oral } \\
\text { epithelial cells. }\end{array}$ & $\begin{array}{l}\text { The extracts from a green tea } \\
\text { and black tea, EGCG and } \\
\text { theaflavins in range } \\
7.9-62.5 \mu \mathrm{g} / \mathrm{mL} \text { were found to } \\
\text { significantly and } \\
\text { dose-dependently reduced } \\
\text { secretion IL-1 } \beta \text { by TNF- } \alpha \\
\text {-treated macrophages (at } \\
62.5 \mu \mathrm{m} / \mathrm{mL} \text { all substances } \\
\text { inhibited the secretion of IL- } 1 \beta \\
\text { by more than } 94 \% \text {, except black } \\
\text { tea- } 64.5 \% \text { ), as well as reduced } \\
\text { the activation of caspase- } 1 \text { and } \\
\text { NF-kB activation. Green tea } \\
\text { extract, theaflavins, EGCG and } \\
\text { to a lesser extent, black tea } \\
\text { extract protected keratinocytes } \\
\text { against the TNF- } \alpha \text {-mediated } \\
\text { breakdown of barrier integrity. } \\
\text { The treatment of keratinocytes } \\
\text { with tea polyphenols markedly } \\
\text { mitigated the morphological } \\
\text { changes of tight junction } \\
\text { proteins such as occludin and } \\
\text { zonula occludens- } 1 . \text { At a } \\
\text { concentration of } 62.5 \mu \text { g } / \mathrm{mL} \text {, } \\
\text { the green tea extract, EGCG, } \\
\text { and theaflavins reduced the } \\
\text { secretion of IL- } 8 \text { by } 93.1 \% \text {, } \\
98.8 \% \text {, and } 70.8 \% \text { respectively. } \\
\text { A much higher concentration of } \\
\text { black tea extract ( } 250 \mu g / m L) \\
\text { was required to reduce the } \\
\text { secretion of IL- } 8 \text { ( } 78 \% \text { ). }\end{array}$ & $\begin{array}{l}\text { Ben Lagha and } \\
\text { Grenier, } 2019\end{array}$ & [16] \\
\hline
\end{tabular}


Table 1. Cont.

\begin{tabular}{|c|c|c|c|c|c|}
\hline $\begin{array}{l}\text { Active Com- } \\
\text { pound/Extract/Fraction }\end{array}$ & Cells/Tissues & Methods & Results & Authors, Year & Ref. \\
\hline $\begin{array}{l}\text { Cranberry } \\
\text { proanthocyanidins (PAs) } \\
\text { isolated from cranberries } \\
\text { (Vaccinium macrocarpon) }\end{array}$ & $\begin{array}{l}\text { U937 human } \\
\text { monocytes } \\
\text { differentiated to } \\
\text { macrophage-like } \\
\text { cells. }\end{array}$ & $\begin{array}{l}\text { Adherent macrophages } \\
\text { were exposed to leukotoxin } \\
\text { LtxA ( } 1 \mu \mathrm{g} / \mathrm{mL}) \text { depending } \\
\text { of the presence of cranberry } \\
\text { PAs. A RealTime-Glo }{ }^{\mathrm{TM} M T} \\
\text { Cell Viability Assay was } \\
\text { performed. The ELISA kit } \\
\text { was used to quantify the } \\
\text { amounts of IL-1 } \beta \text {, IL-18, } \\
\text { and caspase-1 secreted into } \\
\text { the culture medium or } \\
\text { contained in the } \\
\text { macrophages. The P2X7 } \\
\text { receptor and cryopyrin } \\
\text { (CIAS) mRNA expression } \\
\text { was determined by q } \\
\text { RT-PCR analysis. A total } \\
\text { reactive oxygen species } \\
\text { (ROS)/superoxide } \\
\text { detection kit was used to } \\
\text { measure intracellular ROS } \\
\text { production. Influence of } \\
\text { cranberry PAs on binding } \\
\text { of FITC-LtxA to } \\
\text { macrophages was } \\
\text { examined by flow } \\
\text { cytometry. }\end{array}$ & $\begin{array}{l}\text { Cranberry PAs substantially } \\
\text { reduced the cytotoxic effects of } \\
\text { LtxA on macrophages. At the } \\
125 \mu \mathrm{m} / \mathrm{mL} \text { concentration of the } \\
\text { cranberry Pas, the release of } \\
\text { caspase- } 1 \text {, IL-1 } \beta \text {, and IL-18 was } \\
\text { significantly reduced (by } 100 \% \text {, } \\
99.3 \% \text {, and } 98.7 \% \text {, respectively), } \\
\text { compared to cells treated with } \\
\text { LtxA alone. However, this } \\
\text { strong reduction was already } \\
\text { seen with lower concentration- } \\
15.625 \mu \mathrm{m} / \mathrm{mL} \text { of PAs (about } \\
80-90 \% \text { reduction-as can be } \\
\text { read from the graph). In } \\
\text { contrast, the intracellular levels } \\
\text { of these cytokines were } \\
\text { comparable to those of control } \\
\text { cells. } 125 \mu \mathrm{m} / \mathrm{mL} \text { of cranberry } \\
\text { PAs reduced the expression of } \\
\text { P2X7 and CIAS by } 45.8 \% \text { and } \\
30.2 \% \text {, respectively, as well } \\
\text { reduced the ROS and } \\
\text { superoxide production by } 92.2 \% \\
\text { and } 72.7 \% \text {, respectively, } \\
\text { compared to the control } \\
\text { (macrophages exposed only to } \\
\text { LtxA). } 62.5 \mu \mathrm{g} / \mathrm{mL} \text { and } 125 \\
\mu \mathrm{g} / \mathrm{m} \text { of cranberry PAs blocked } \\
\text { the binding of FITC-LtxA to } \\
\text { macrophages by about } 50 \% \text {. }\end{array}$ & $\begin{array}{l}\text { Ben Lagha et al, } \\
2019\end{array}$ & [17] \\
\hline $\begin{array}{l}\text { The buds of Castanopsis } \\
\text { lamontii Hance water } \\
\text { extract (CLE) rich in } \\
\text { epicatechin and } \\
\text { procyanidin B2; } \\
\text { epicatechin (EC); } \\
\text { procyanidin B2 (PB2) }\end{array}$ & $\begin{array}{l}\text { Mouse macrophage } \\
\text { RAW264.7 cells. }\end{array}$ & $\begin{array}{l}\text { The RAW264.7 cells were } \\
\text { cotreated or pretreated with } \\
\text { LPS and CLE/EC/PB2 and } \\
\text { then the expression of } \\
\text { TLR-4 pathway-related } \\
\text { proteins (TLR-4, p-NF-kB } \\
\text { (p65), iNOS, and COX-2) } \\
\text { and the release of NO, } \\
\text { PGE2, and TNF- } \alpha \text { were } \\
\text { determined. The } \\
\text { concentration of NO, PGE2, } \\
\text { TNF- } \alpha \text { was measured using } \\
\text { appropriate test kits The } \\
\text { Western Blot (WB) assay } \\
\text { was used in the study to } \\
\text { determine the expression of } \\
\text { TLR-4, p-NF-kB (p65), } \\
\text { iNOS, and COX-2. }\end{array}$ & $\begin{array}{l}\text { CLE }(400 \mu \mathrm{g} / \mathrm{mL}) \text { and two } \\
\text { compounds-PB2 }(34.4 \mu \mathrm{g} / \mathrm{mL}) \\
\text { and EC }(120 \mu \mathrm{g} / \mathrm{mL}) \\
\text { (equivalent to the concentration } \\
\text { of PB2 and EC in } 400 \mu \mathrm{g} / \mathrm{mL} \\
\text { CLE) significantly decreased the } \\
\text { release of NO, PGE2, and } \\
\text { TNF- } \alpha \text { from LPS-stimulated } \\
\text { macrophages in LPS cotreated } \\
\text { and pretreated group as well as } \\
\text { decreased } \\
\text { Lipopolysaccharide-stimulated } \\
\text { up-regulation of TLR4, p-NF- } \mathrm{kB} \\
\text { (p65), COX-2, and iNOS in } \\
\text { RAW264.7 cells. Compared } \\
\text { with EC, PB2 was much more } \\
\text { potent in suppressing the } \\
\text { LPS-stimulated inflammatory } \\
\text { response. }\end{array}$ & Gao et al., 2019 & [18] \\
\hline
\end{tabular}


Table 1. Cont.

\begin{tabular}{|c|c|c|c|c|c|}
\hline $\begin{array}{l}\text { Active Com- } \\
\text { pound/Extract/Fraction }\end{array}$ & Cells/Tissues & Methods & Results & Authors, Year & Ref. \\
\hline $\begin{array}{l}\text { Highbush blueberry } \\
\text { (Vaccinium corymbosum L.) } \\
\text { proanthocyanidins (PAs) }\end{array}$ & $\begin{array}{l}\text { U937 human } \\
\text { monocytes } \\
\text { differentiated to } \\
\text { macrophage-like } \\
\text { cells. }\end{array}$ & $\begin{array}{l}\text { In the study adherent } \\
\text { macrophage like cells were } \\
\text { pre-treated with the PAs } \\
\text { and then stimulated with } A \text {. } \\
\text { actinomycetemcomitans LPS. } \\
\text { ELISA was used to quantify } \\
\text { the secretion of } \\
\text { pro-inflammatory cytokines } \\
\text { (IL-1ß, TNF- } \alpha \text {, IL-6 and } \\
\text { C-X-C motif chemokine } \\
\text { ligand CXCL8) and MMPs } \\
\text { (MMP-3 and MMP-9). } \\
\text { NF-kB activation was } \\
\text { monitored by using the } \\
\text { U937-3xkB-LUC monocyte } \\
\text { cell line transfected with a } \\
\text { luciferase reporter gene. } \\
\text { MTT assay was used to } \\
\text { determine viability of cells } \\
\text { treatment with PAs. }\end{array}$ & $\begin{array}{l}\text { PAs significantly and } \\
\text { dose-dependently decreased } \\
\text { secretion of pro-inflammatory } \\
\text { cytokines from LPS-stimulated } \\
\text { macrophages. PAs at } \\
125 \mu \mathrm{g} / \mathrm{mL} \text { reduced the } \\
\text { secretion of IL-1 } \beta, \text { TNF- } \alpha \text {, IL- } 6 \text {, } \\
\text { and CXCL8 by } 75.34 \%, 81.64 \% \text {, } \\
48.27 \% \text {, and } 90.19 \% \text {, } \\
\text { respectively, whereas MMP-9 } \\
\text { and MMP-3 secretion was } \\
\text { attenuated by } 68.78 \% \text { and } \\
\text { 93.04\%, respectively. The PAs } \\
\text { were also found to inhibit the } \\
\text { activation of the nuclear } \\
\text { factor- } \kappa B \text { (NF- } \mathrm{kB} \text { ) signaling } \\
\text { pathway. }\end{array}$ & $\begin{array}{l}\text { Ben Lagha et al., } \\
2018\end{array}$ & [19] \\
\hline $\begin{array}{l}\text { Mixture of theaflavins } \\
\text { (TFs) from black tea } \\
\text { (theaflavin-3-gallate, } \\
\text { theaflavin- } 3^{\prime} \text {-gallate and } \\
\text { theaflavin-3-3'-digallate, } \\
\text { with more than } 80 \% \\
\text { purity) }\end{array}$ & $\begin{array}{l}\text { Gingival keratinocyte } \\
\text { cell line, B11; U937 } \\
\text { human monocytes } \\
\text { differentiated to } \\
\text { macrophage-like } \\
\text { cells. }\end{array}$ & $\begin{array}{l}\text { Adherent macrophage like } \\
\text { cells were pretreated with } \\
\text { the TFs and stimulated } \\
\text { with } P \text {. gingivalis. Secreted } \\
\text { matrix metalloproteinase } \\
\text { (MMP-3, MMP-8, MMP-9) } \\
\text { and pro-inflammatory } \\
\text { cytokines (IL-1 } \beta \text {, TNF- } \alpha \text {, IL- } \\
6 \text {, and CXCL8) were then } \\
\text { quantified by ELISA. Effect } \\
\text { of theaflavins (TFs) on the } \\
\text { activity of MMP-9 was } \\
\text { monitored using a } \\
\text { fluorogenic assay. NF- } \mathrm{B} \text { B } \\
\text { activation was monitored } \\
\text { by using the } \\
\text { U937-3xkB-LUC monocyte } \\
\text { cell line transfected with a } \\
\text { luciferase reporter gene. } \\
\text { MTT assay was used to } \\
\text { determine viability of cells } \\
\text { treatment with TFs. }\end{array}$ & $\begin{array}{l}\text { At a concentration of } \\
125 \mu \mathrm{g} / \mathrm{mL} \text {, the TFs have } \\
\text { reduced the secretion of } \\
\text { Interleukin } 1 \text { beta by } 98.4 \% \text {, } \\
\text { TNF- } \alpha \text { by } 98.8 \% \text {, Interleukin } 6 \\
\text { by } 97.7 \% \text { and of CXCL } 8 \text { by } 84 \% \\
\text { compared to the controls as well } \\
\text { reduced the secretion of MMP-3 } \\
\text { by } 97.3 \%, \text { MMP- } 8 \text { by } 99.9 \% \text {, } \\
\text { MMP- } 9 \text { by } 95.7 \% \text {. The TFs } \\
\text { mixture at } 125 \mu \mathrm{g} / \mathrm{mL} \text { reduced } \\
\text { MMP- } 9 \text { activity by } 100 \% \text {. The } \\
\text { TFs inhibited the activation of } \\
\text { the NF- } \mathrm{BB} \text { signaling pathway. }\end{array}$ & $\begin{array}{l}\text { Ben Lagha and } \\
\text { Grenier, } 2017\end{array}$ & [20] \\
\hline $\begin{array}{l}80 \% \text { methanol extract of } \\
\text { green tea (Camellia } \\
\text { sinensis (L.) Kuntze) and } \\
\text { commercially purchased } \\
\text { epigallocatechin-gallate } \\
\text { (EGCG) }\end{array}$ & Human neutrophils. & $\begin{array}{l}\text { Methanol extract and } \\
\text { EGCG were tested in vitro } \\
\text { environment for their } \\
\text { ability to inhibit MMP-9 } \\
\text { activity and/or its release } \\
\text { from neutrophils using a } \\
\text { b-casein cleavage assay and } \\
\text { gelatin zymography, } \\
\text { respectively. }\end{array}$ & $\begin{array}{l}\text { Methanol extract and EGCG at } \\
0.1 \%(w / v) \text { has completely } \\
\text { inhibited the activity of matrix } \\
\text { metalloproteinase- } 9 \text {, as well } \\
\text { significantly inhibited the } \\
\text { release of MMP-9 from } \\
\text { formyl-Met-Leu-Phe-OH } \\
\text { (FMLP) stimulated human } \\
\text { neutrophils by } 62.01 \% \text { and } \\
79.63 \% \text {, respectively and from } \\
\text { unstimulated neutrophils } \\
\text { (52.42\% and } 62.33 \% \text {, } \\
\text { respectively). }\end{array}$ & $\begin{array}{l}\text { Kim-Park et al., } \\
2016\end{array}$ & [21] \\
\hline
\end{tabular}


Table 1. Cont.

\begin{tabular}{|c|c|c|c|c|c|}
\hline $\begin{array}{l}\text { Active Com- } \\
\text { pound/Extract/Fraction }\end{array}$ & Cells/Tissues & Methods & Results & Authors, Year & Ref. \\
\hline $\begin{array}{l}70 \% \text { ethanolic blueberry } \\
\text { extract (Vaccinium } \\
\text { angustifolium } \\
\text { Ait.)_phenolic acids, } \\
\text { flavonoids and } \\
\text { procyanidins made up } \\
16.6 \%, 12.9 \% \text {, and } 2.7 \% \text { of } \\
\text { the blueberry extract, } \\
\text { respectively }\end{array}$ & $\begin{array}{l}\text { U937 human } \\
\text { monocytes } \\
\text { differentiated to } \\
\text { macrophage-like } \\
\text { cells. }\end{array}$ & $\begin{array}{l}\text { The macrophage like cells } \\
\text { were pretreated with the } \\
\text { blueberry extract and then } \\
\text { stimulated with } F \text {. } \\
\text { nucleatum. ELISA kits were } \\
\text { used to quantify IL-1 } \beta \text {, IL-6, } \\
\text { CXCL8, TNF- } \alpha \text {, MMP-8, } \\
\text { and MMP-9 concentrations. } \\
\text { Activity of MMP-9 was } \\
\text { monitored using } \\
\text { fluorogenic assay. The } \\
\text { ability of the blueberry } \\
\text { extract to inhibit the NF-кB } \\
\text { signaling pathway in } \\
\text { U937-3xkB cells was } \\
\text { evaluated in the study. }\end{array}$ & $\begin{array}{l}\text { The blueberry extract was } \\
\text { found to dose-dependently } \\
\text { inhibit the activation of NF- } \mathrm{BB} \\
\text { induced by Fusobacterium } \\
\text { nucleatum. A pre-treatment of } \\
\text { macrophages with the tested } \\
\text { blueberry extract ( } 62.5 \mu \mathrm{g} / \mathrm{mL} \text { ) } \\
\text { has inhibited the secretion of } \\
\text { interleukin } 1 \text { beta, TNF- } \alpha \text {, and } \\
\text { interleukin } 6 \text { by } 87.3 \%, 80.7 \% \text {, } \\
\text { and } 28.2 \% \text {, respectively. The } \\
\text { secretion of the chemokine } \\
\text { CXCL } 8 \text { was not affected by } \\
62.5 \mu \mathrm{m} / \mathrm{mL} \text { of the tested } \\
\text { blueberry extract, but } \\
500 \mu \mathrm{m} / \mathrm{mL}, 250 \mu \mathrm{m} / \mathrm{mL} \text {, or } 125 \\
\mu \mathrm{m} / \mathrm{mL} \text { extract have decreased } \\
\text { the secretion of the CXCL8 by } \\
79 \%, 57.9 \% \text {, and } 11.2 \% \\
\text { respectively. The secretion of } \\
\mathrm{MMP}-8 \text { and MMP- } 9 \text { was also } \\
\text { dose-dependently inhibited as } \\
\text { well MMP-9 activity. }\end{array}$ & $\begin{array}{l}\text { Ben Lagha et al., } \\
2015\end{array}$ & [22] \\
\hline $\begin{array}{l}\text { type-A cranberry } \\
\text { proanthocyanidins } \\
\text { (AC-PAs) and } \\
\text { epigallocatechin-3- } \\
\text { gallate } \\
\text { (EGCG) }\end{array}$ & $\begin{array}{l}\text { A 3D co-culture } \\
\text { model composed of } \\
\text { gingival fibroblasts } \\
\text { embedded in a } \\
\text { collagen matrix and } \\
\text { overlaid with } \\
\text { gingival } \\
\text { epithelial cells. }\end{array}$ & $\begin{array}{l}\text { The 3D co-culture model } \\
\text { treated with the } \\
\text { concentrations of AC-PAs } \\
\text { that are not cytotoxic ( } 25 \text { or } \\
50 \mu \mathrm{g} / \mathrm{mL} \text { ), EGCG ( } 1 \text { or } \\
5 \mu \mathrm{g} / \mathrm{mL} \text { ) and LL-37 } \\
\text { (peptide cathelicidin) } \\
\text { individually and in } \\
\text { combination } \\
\text { (AC-PAs+LL-37 and } \\
\text { EGCG+LL-37) were } \\
\text { stimulated with LPS from } \\
\text { the A. } \\
\text { actinomycetemcomitans. } \\
\text { Multiplex ELISA assays } \\
\text { were used to quantify the } \\
\text { secretion of } 54 \text { host factors, } \\
\text { among them were } \\
\text { chemokines, cytokines, } \\
\text { growth factors MMPs, and } \\
\text { tissue inhibitors of } \\
\text { metallopeptidases (TIMPs). }\end{array}$ & 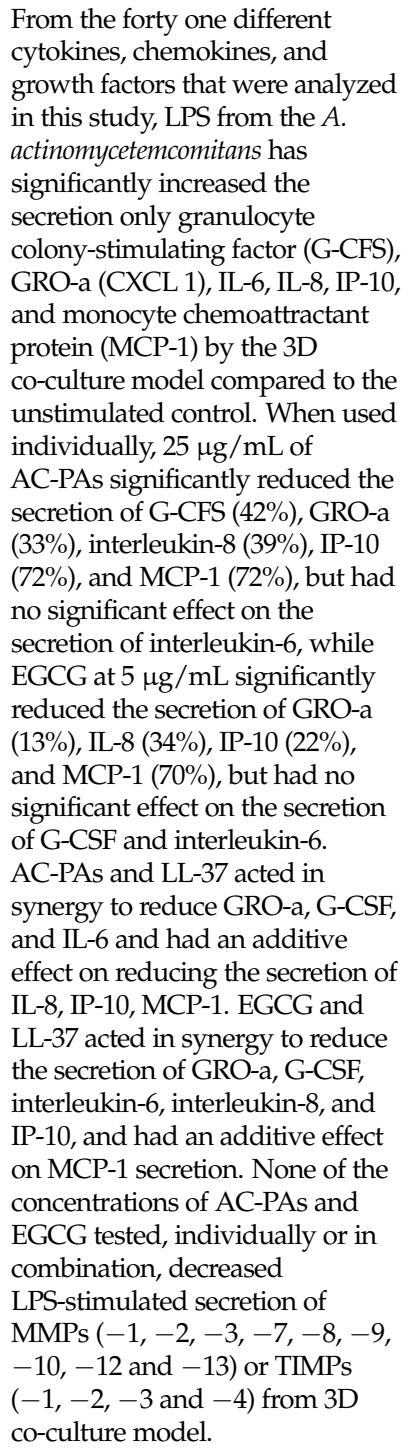 & $\begin{array}{l}\text { Lombardo } \\
\text { Bedran et al. } \\
2015\end{array}$ & [23] \\
\hline
\end{tabular}


Table 1. Cont.

\begin{tabular}{|c|c|c|c|c|c|}
\hline $\begin{array}{l}\text { Active Com- } \\
\text { pound/Extract/Fraction }\end{array}$ & Cells/Tissues & Methods & Results & Authors, Year & Ref. \\
\hline $\begin{array}{l}\text { Commercial black tea } \\
\text { extract (with theaflavin } \\
\text { content of } 40.23 \% \text { ); } \\
\text { theaflavin, } \\
\text { theaflavin-3,3'-digallate, } \\
\text { epigallocatechin-3- } \\
\text { gallate } \\
\text { EGCG }\end{array}$ & $\begin{array}{l}\text { The oral epithelial } \\
\text { cells (OBA-9). }\end{array}$ & $\begin{array}{l}\text { The epithelial cells were } \\
\text { pretreated with the extract } \\
\text { form black tea, theaflavin, } \\
\text { theaflavin- } 3,3^{\prime} \text {-digallate or } \\
\text { EGCG prior to being } \\
\text { stimulated with } A \text {. } \\
\text { actinomycetemcomitans } \\
\text { lipopolysaccharide. ELISA } \\
\text { assays were used to } \\
\text { quantify the secretion of } \\
\text { IL- } 8, \text { human } \beta \text {-defensins } \\
\text { (hBD- } 1, \text { hBD- } 2 \text { and hBD- } 4 \text { ) } \\
\text { by OBA-9 cells. }\end{array}$ & $\begin{array}{l}\text { The extract obtained from the } \\
\text { black tea }(200 \mu \mathrm{g} / \mathrm{mL}) \text {, as well } \\
\text { as theaflavin }(50 \mu \mathrm{g} / \mathrm{mL}) \text { and } \\
\text { theaflavin- } 3,3^{\prime} \text {-digallate } \\
(50 \mu \mathrm{g} / \mathrm{mL}) \text { reduced IL- } 8 \\
\text { secretion by } 85 \%, 79 \% \text {, and } 86 \% \text {, } \\
\text { respectively. EGCG used as a } \\
\text { positive control reduced IL- } 8 \\
\text { little stronger. The secretion of } \\
\text { all } 3 \text { hBD antimicrobial peptides } \\
\text { was up-regulated } \\
\text { dose-dependently. Only } \\
\text { theaflavin did not induce the } \\
\text { secretion of significant amounts } \\
\text { of hBDs from OBA- } 9 \text { cells. }\end{array}$ & $\begin{array}{l}\text { Lombardo } \\
\text { Bedran et al., } \\
2015\end{array}$ & [24] \\
\hline $\begin{array}{l}\text { The commercial green tea } \\
\text { extract with polyphenol } \\
\text { content } \geq 98 \% \text {, including } \\
45 \% \text { epigallocatechin-3- } \\
\text { gallate } \\
\text { EGCG }\end{array}$ & $\begin{array}{l}\text { The immortalized } \\
\text { human gingival } \\
\text { epithelial cell line, } \\
\text { B11. }\end{array}$ & $\begin{array}{l}\text { Immortalized human } \\
\text { gingival cells from } \\
\text { epithelium were treated } \\
\text { with various amounts of } \\
\text { extract from green tea or } \\
\text { EGCG (from } 25 \mu \mathrm{g} / \mathrm{mL} \text { up } \\
\text { to } 200 \mu \mathrm{g} / \mathrm{mL} \text { ). ELISA was } \\
\text { used to measure the } \\
\text { secretion of hBD1 and } \\
\text { hBD2 and real-time PCR } \\
\text { was used to evaluate their } \\
\text { gene expression. The ability } \\
\text { of tested tea extract and } \\
\text { EGCG to prevent hBD } \\
\text { degradation by } \\
\text { Porphyromonas gingivalis } \\
\text { was evaluated by ELISA. }\end{array}$ & $\begin{array}{l}\text { Tested extract from green tea } \\
\text { and EGCG dose-dependently } \\
\text { induced the secretion of hBD1 } \\
\text { and hBD2 from gingival } \\
\text { epithelial cells. They increased } \\
\text { expression of the hBD gene in } \\
\text { tested epithelial cells. Green tea } \\
\text { or EGCG-induced secretion of } \\
\text { hBD1 and hBD2 appeared to } \\
\text { involve ERK1/2 and p38 } \\
\text { MAPK. Green tea extract and } \\
\text { EGCG prevented the } \\
\text { degradation of recombinant } \\
\text { hBD1 and hBD2 by a culture } \\
\text { supernatant of } P \text {. gingivalis. }\end{array}$ & $\begin{array}{l}\text { Lombardo } \\
\text { Bedran et al., } \\
2014\end{array}$ & {$[25]$} \\
\hline $\begin{array}{l}\text { Non-dialyzable material } \\
\text { (NDM) prepared from } \\
\text { concentrated cranberry } \\
\text { (Vaccinium macrocarpon) } \\
\text { juice, containing } 65.1 \% \\
\text { proanthocyanidins. }\end{array}$ & $\begin{array}{l}\text { The } \\
\text { Smulow-Glickman } \\
\text { (S-G) human gingival } \\
\text { epithelial cell line. }\end{array}$ & $\begin{array}{l}\text { S-G cells were incubated } \\
\text { with IL-1 } \beta \text { in the presence } \\
\text { or absence of NDM or } \\
\text { inhibitors of NF- } \mathrm{k} \text { B-NBD or } \\
\text { AP-1-SP } 600125 \text {. The IL- } 6 \\
\text { levels were measured by } \\
\text { ELISA kit. Effects of NDM } \\
\text { on IL-1 } 13 \text {-activated NF- } \mathrm{B} \\
\text { and AP-1 and } \\
\text { phosphorylated } \\
\text { intermediates in both } \\
\text { pathways were measured } \\
\text { by ELISAs. }\end{array}$ & 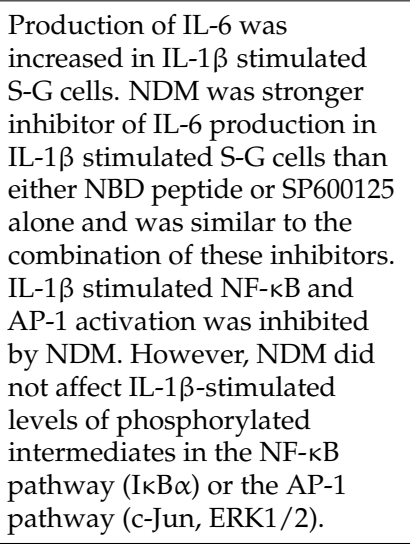 & Tipton et al., 2014 & [26] \\
\hline Same as above & $\begin{array}{l}\text { The } \\
\text { Smulow-Glickman } \\
\text { (S-G) human gingival } \\
\text { epithelial cell line; } \\
\text { normal human } \\
\text { gingival fibroblasts. }\end{array}$ & $\begin{array}{l}\text { S-G and normal human } \\
\text { gingival fibroblasts were } \\
\text { incubated with NDM, IL-17, } \\
\text { or NDM+IL-17. IL-6 and } \\
\text { IL- } 8 \text { in culture supernatants } \\
\text { were measured by ELISA. }\end{array}$ & $\begin{array}{l}\text { In both cell lines, IL- } 17 \text { has been } \\
\text { found to significantly stimulate } \\
\text { the production of IL- } 6 \text { and IL- } 8 \text {. } \\
\text { Non cytotoxic levels of NDM } \\
\text { ( } 5-50 \mu \mathrm{g} / \mathrm{mL}) \text { inhibited } \\
\text { constitutive IL- } 6 \text { and IL- } 8 \\
\text { production as well their } \\
\text { IL-17-stimulated cytokine } \\
\text { production by epithelial cells } \\
\text { and fibroblasts. }\end{array}$ & Tipton et al., 2013 & [27] \\
\hline
\end{tabular}


Table 1. Cont.

\begin{tabular}{|c|c|c|c|c|c|}
\hline $\begin{array}{l}\text { Active Com- } \\
\text { pound/Extract/Fraction }\end{array}$ & Cells/Tissues & Methods & Results & Authors, Year & Ref. \\
\hline Same as above & $\begin{array}{l}\text { Human gingival } \\
\text { fibroblast cell line } \\
\text { derived from patient } \\
\text { with aggressive } \\
\text { periodontitis (AgP); } \\
\text { Normal human } \\
\text { gingival fibroblast } \\
\text { cell lines (GN23, } \\
\text { GN56, GN60). }\end{array}$ & $\begin{array}{l}\text { AgP or normal fibroblasts } \\
\text { were incubated with NDM } \\
\text { or LPS (from Fusobacterium } \\
\text { nucleatum or Porphyromonas } \\
\text { gingivalis) } \pm \text { NDM. The cell } \\
\text { viability and membrane } \\
\text { damage were tested by } \\
\text { MTT assay and enzyme } \\
\text { activity released into cell } \\
\text { supernatant, respectively. } \\
\text { ELISA was used to measure } \\
\text { IL-6 and MMP-3 secretion. } \\
\text { Nuclear p65 levels were } \\
\text { measured using a } \\
\text { colorimetric assay. }\end{array}$ & $\begin{array}{l}\text { NDM } \leq 100 \mu \mathrm{g} / \mathrm{mL} \text { showed no } \\
\text { significant effect on tested AgP } \\
\text { fibroblast viability, but higher } \\
\text { concentration decreased their } \\
\text { viability. No membrane damage } \\
\text { was seen after short-term } \\
\text { exposure to NDM, or LPS } \pm \\
\text { NDM. NDM ( } 50 \mu \mathrm{g} / \mathrm{mL}) \\
\text { inhibited LPS-stimulated } \\
\text { nuclear p65 levels (by } 25 \% \text { for } \\
\text { LPS from F. nucleatum and by } \\
80 \% \text { for LPS from } P \text {. gingivalis) } \\
\text { as well inhibited constitutive or } \\
\text { LPS-stimulated MMP-3 in AgP } \\
\text { fibroblasts. NDM increased IL-6 } \\
\text { in LPS-stimulated AgP } \\
\text { fibroblast but decreased in } \\
\text { normal human gingival } \\
\text { fibroblast. }\end{array}$ & Tipton et al., 2013 & [28] \\
\hline $\begin{array}{l}\text { Non-dialyzable material } \\
\text { (NDM) prepared from } \\
\text { concentrated cranberry } \\
\text { (Vaccinium macrocarpon) } \\
\text { juice, rich in } \\
\text { proanthocyanidins }\end{array}$ & $\begin{array}{l}\text { RAW } 264.7 \text { mouse } \\
\text { macrophages. }\end{array}$ & $\begin{array}{l}\text { RAW } 264.7 \text { mouse } \\
\text { macrophages were exposed } \\
\text { to culture media (P. } \\
\text { gingivalis and F. nucleatum) } \\
\text { with or without NDM } \\
\text { ( } 4 \mathrm{mg} / \mathrm{mL}) \text {. The secreted } \\
\text { form of mouse TNF- } \alpha \text { was } \\
\text { quantified using two-site } \\
\text { ELISA. Macrophage } \\
\text { functionality was } \\
\text { investigated using a } \\
\text { phagocytosis assay. }\end{array}$ & $\begin{array}{l}\text { NDM completely inhibited } \\
\text { bacteria's increased expression } \\
\text { of TNF- } \alpha \text { in macrophages } \\
\text { without reducing their viability. } \\
\text { Furthermore, the addition of } \\
\text { NDM caused increasing the } \\
\text { phagocytosis of } P \text {. gingivalis } \\
\text { (from } 10 \% \text { to } 20 \% \text { ), and little } \\
\text { reduction in the phagocytosis of } \\
\text { F. nucleatum (from } 50 \text { to } 40 \% \text { ). }\end{array}$ & Polak et al., 2013 & [29] \\
\hline $\begin{array}{l}\text { (-)-Epigallocatechin } \\
\text { gallate (EGCG) }\end{array}$ & $\begin{array}{l}\text { Human gingival } \\
\text { fibroblasts (HGFs). }\end{array}$ & $\begin{array}{l}\text { HGFs were cultured in the } \\
\text { presence or absence of } \\
\text { EGCG }(3.125-50 \mu \mathrm{g} / \mathrm{mL}) \\
\text { prior to their incubation } \\
\text { with IL- } 1 \beta+\text { IL- } 4 \text { or TNF- } \alpha \\
\text { + IL-4-stimulations, then the } \\
\text { CCL11 concentrations were } \\
\text { measured with ELISA. } \\
\text { Western blot analysis was } \\
\text { used in the study to } \\
\text { confirm the effects of EGCG } \\
\text { on IL-1 } \beta \text { IL-4 or TNF- } \alpha+ \\
\text { IL-4-induced } \\
\text { phosphorylation of signal } \\
\text { transduction molecules. }\end{array}$ & $\begin{array}{l}\text { IL- } 4 \text { was found to } \\
\text { synergistically enhance CCL11 } \\
\text { production in IL-1 } \beta \text { or } \\
\text { TNF- } \alpha \text {-stimulated HGFs. } \\
\text { EGCG reduced production of } \\
\text { CCL11 in IL-1 } \beta \text { /IL- } 4 \text { or } \\
\text { TNF- } \alpha / \text { IL-4-stimulated HGFs, } \\
\text { in a concentration dependent } \\
\text { manner. CCL11 production in } \\
\text { HGFs was positively regulated } \\
\text { by p38 MAPK, ERK, and JNK. } \\
\text { EGCG prevented activation of } \\
\text { ERK and JNK, but not p38 } \\
\text { MAPK, induced by IL-1 } \beta / \text { IL-4 } \\
\text { or TNF- } \alpha / \text { IL-4-in HGF. }\end{array}$ & $\begin{array}{l}\text { Hosokawa et al., } \\
2013\end{array}$ & [30] \\
\hline $\begin{array}{l}\text { A-type cranberry } \\
\text { proanthocyanidins } \\
\text { (APAC) and licochalcone } \\
\text { A (LA)-chalcone, not } \\
\text { proanthocyanidin }\end{array}$ & $\begin{array}{l}\text { U937 human } \\
\text { monocytes } \\
\text { differentiated to } \\
\text { macrophages. }\end{array}$ & $\begin{array}{l}\text { IL-1 } \beta, \text { TNF- } \alpha \text {, IL- } 6 \text {, and } \\
\text { IL-8 production by } \\
\text { macrophages treated with } \\
\text { the APAC (or/and LA) and } \\
\text { stimulated by } A \text {. } \\
\text { actinomycetemcomitans LPS } \\
\text { was evaluated by ELISA } \\
\text { kits. Influence of APAC } \\
\text { (or/and LA) on MMP-9 and } \\
\text { Porphyromonas gingivalis } \\
\text { collagenase activities was } \\
\text { measured using } \\
\text { fluorometric assays. } \\
\text { Macrophages viability was } \\
\text { evaluated with MTT assay. }\end{array}$ & $\begin{array}{l}\text { ACPAC in } 25 \mu \mathrm{g} / \mathrm{mL} \text { or } \\
50 \mu \mathrm{g} / \mathrm{mL} \text { concentration } \\
\text { reduced the LPS-induced } \\
\text { secretion of TNF- } \alpha \text {, IL- } 6 \text { and } \\
\text { IL- } 8 \text { in a macrophage model, } \\
\text { but not IL- } 1 \beta \text {. A reduction in } \\
\text { secretion of IL- } 1 \beta \text { was seen } \\
\text { when ACPAC was used } \\
\text { together with LA. ACPAC } \\
\text { ( } 25 \mu \mathrm{g} / \mathrm{mL} \text { ) inhibited MMP-9 } \\
\text { activity by } 32 \% \text { and } P \text {. gingivalis } \\
\text { collagenase by } 66 \% \text {. }\end{array}$ & $\begin{array}{l}\text { Feldman and } \\
\text { Grenier, } 2012\end{array}$ & [31] \\
\hline
\end{tabular}


Table 1. Cont.

\begin{tabular}{|c|c|c|c|c|c|}
\hline $\begin{array}{l}\text { Active Com- } \\
\text { pound/Extract/Fraction }\end{array}$ & Cells/Tissues & Methods & Results & Authors, Year & Ref. \\
\hline $\begin{array}{l}\text { AC-PAs fraction from } \\
\text { cranberries (Vaccinium } \\
\text { macrocarpon) }\end{array}$ & $\begin{array}{l}\text { Human osteoclast } \\
\text { precursor cells. }\end{array}$ & $\begin{array}{l}\text { This study investigated the } \\
\text { influence of the AC-PAs on } \\
\text { osteoclast formation and } \\
\text { bone resorption. The } \\
\text { degree of osteoclast } \\
\text { formation was assessed by } \\
\text { quantification of } \\
\text { TRAP-positive stained } \\
\text { multinucleated cells, while } \\
\text { the secretion of IL-8 and } \\
\text { MMP-2, MMP-9 was } \\
\text { measured with ELISA. } \\
\text { Bone resorption was } \\
\text { evaluated using a human } \\
\text { bone plate coupled with an } \\
\text { immunoassay that detected } \\
\text { the release of collagen } \\
\text { helical peptides. MTT assay } \\
\text { was used to measure the } \\
\text { cytotoxic effect of AC-PAs } \\
\text { on osteoclastic cells. }\end{array}$ & $\begin{array}{l}\text { AC-PAs at } 10 \mu \mathrm{g} / \mathrm{mL} \text {, } \\
25 \mu \mathrm{g} / \mathrm{mL}, \text { and } 50 \mu \mathrm{g} / \mathrm{mL} \\
\text { caused a } 38 \%, 84 \% \text {, and } 95 \% \\
\text { inhibition of } \\
\text { RANKL-dependent osteoclast } \\
\text { differentiation, respectively. } \\
\text { AC-PAs increased the secretion } \\
\text { of IL-8 and inhibited the } \\
\text { secretion of both MMP-2 and } \\
\text { MMP-9 in a dose-dependent } \\
\text { manner. AC-PAs significantly } \\
\text { decreasing the release of } \\
\text { collagen helical peptides } \\
\text { suggested that can prevent } \\
\text { bone resorption. AC-PAs did } \\
\text { not exhibit any toxic effect on } \\
\text { osteoclastic cells from } \\
10 \mu \mathrm{g} / \mathrm{mL} \text { to } 100 \mu \mathrm{g} / \mathrm{mL} \text {. }\end{array}$ & $\begin{array}{l}\text { Tanabe et al., } \\
2011\end{array}$ & [32] \\
\hline $\begin{array}{l}50 \% \text { EtOH extract from } \\
\text { Myrothamnus flabellifolia } \\
\text { Welw. (MF) }\end{array}$ & $\begin{array}{l}\text { KB cells (ATCC } \\
\text { CCL-17, HeLa). }\end{array}$ & $\begin{array}{l}\text { KB cells were pretreated } \\
\text { with MF }(10 \mu \mathrm{g} / \mathrm{mL} \text { and } \\
100 \mu \mathrm{g} / \mathrm{mL}) \text { and infected } \\
\text { with } P \text {. gingivalis. The } \\
\text { cytokine gene expression } \\
\text { was monitored using } \\
\text { RT-qPCR and IL-6 level } \\
\text { using ELISA. }\end{array}$ & $\begin{array}{l}10 \text { and } 100 \mu \mathrm{g} / \mathrm{mL} \text { of MF } \\
\text { significantly decreased } \\
\text { (upregulated by P. gingivalis) } \\
\text { gene expression for IL-1 } \beta, \text { IL- } 8 \\
\text { and TNF- } \alpha \text {, but not IL- } 6 \\
\text { compare to control cells (not } \\
\text { exposed to tested extract). } \\
\text { However, preincubation of the } \\
\text { KB cells with MF before } \\
\text { exposure to } P . \text { gingivalis resulted } \\
\text { in significant lower } \\
\text { concentration of IL- } 6 \text { in the cells } \\
\text { than in MF-untreated control } \\
\text { group. }\end{array}$ & Löhr et al., 2011 & [33] \\
\hline
\end{tabular}

HDPC were pretreated with or without EGCG or ECG $(1-50 \mu \mathrm{g} / \mathrm{mL})$ for $1 \mathrm{~h}$, and incubated with E. coli LPS $(1 \mu \mathrm{g} / \mathrm{mL})$ or $S$. aureus PG $(10 \mu \mathrm{g} / \mathrm{mL})$ for $4 \mathrm{~h}$ or $24 \mathrm{~h}$. After incubation, the quantities of IL-6 and IL-8 (by ELISA) were

Epigallocatechin-3gallate (EGCG) and epicatechin-3-gallate (ECG)
Human dental pulp cells (HDPC) determined, and the attached cells were used for RNA extraction (gene expression of IL-6 and IL-8 using the RT-qPCR) or flow cytometric analysis (for expression of intercellular adhesion molecule- 1 (ICAM-1) and of vascular cell adhesion molecule- 1 (VCAM-1))
Treatment with EGCG and ECG significantly reduced, in a concentration-dependent manner, IL-6 and IL-8 mRNAs and the respective proteins level in dental pulp cells exposed to LPS or PG. Up-regulated 2010
-1 or VCAM-1 expression on LPS or PG stimulated HDPC was decreased by treatment with EGCG or ECG. 
Table 1. Cont.

\begin{tabular}{|c|c|c|c|c|c|}
\hline $\begin{array}{l}\text { Active Com- } \\
\text { pound/Extract/Fraction }\end{array}$ & Cells/Tissues & Methods & Results & Authors, Year & Ref. \\
\hline $\begin{array}{l}\text { Epigallocatechin gallate } \\
\text { (EGCG) and epicatechin } \\
\text { gallate (ECG) }\end{array}$ & $\begin{array}{l}\text { Human gingival } \\
\text { fibroblasts (HGFs) } \\
\text { isolated from healthy } \\
\text { gingiva. }\end{array}$ & $\begin{array}{l}\text { HGFs cultured in the } \\
\text { presence or absence of } \\
\text { EGCG or ECG prior to their } \\
\text { incubation with Oncostatin } \\
\text { M (OSM), then the CXCL10 } \\
\text { concentrations of the } \\
\text { culture supernatants were } \\
\text { measured with ELISA. The } \\
\text { effects of EGCG and ECG } \\
\text { on the p38 MAPK, JNK, } \\
\text { Akt, and STAT3 } \\
\text { phosphorylation induced } \\
\text { by OSM in HGFs was } \\
\text { measured using Western } \\
\text { blotting analysis with } \\
\text { antibodies. The effects of } \\
\text { EGCG or ECG on OSMR } \beta \\
\text { expression on HGFs were } \\
\text { measured using flow } \\
\text { cytometry. }\end{array}$ & $\begin{array}{l}\text { EGCG or ECG }(50 \mu \mathrm{g} / \mathrm{mL}) \\
\text { significantly inhibited (about } \\
60 \% \text { ) the CXCL10 production } \\
\text { induced by OSM treatment. } \\
\text { EGCG }(50 \mu \mathrm{g} / \mathrm{mL}) \text { significantly } \\
\text { prevented OSM induced } \\
\text { phosphorylation of JNK, Akt } \\
\text { (Ser473) and STAT3 (Tyr705 and } \\
\text { Ser727), whereas ECG (m) } \\
\text { prevented phosphorylation of } \\
\text { JNK and Akt (Ser473). EGCG } \\
\text { and ECG attenuated OSMR } \beta \\
\text { expression on HGFs. }\end{array}$ & $\begin{array}{l}\text { Hosokawa et al., } \\
\text { 2010a }\end{array}$ & [35] \\
\hline $\begin{array}{l}\text { Epigallocatechin gallate } \\
\text { (EGCG), epicatechin } \\
\text { gallate (ECG), } \\
\text { theaflavin-3,3'-digallate } \\
\text { (TFDG) }\end{array}$ & $\begin{array}{l}\text { Human gingival } \\
\text { fibroblasts (HGFs) } \\
\text { isolated from healthy } \\
\text { gingiva. }\end{array}$ & $\begin{array}{l}\text { HGFs were cultured in the } \\
\text { presence or absence of } \\
\text { EGCG, ECG, and TFDG } \\
(5 \mu \mathrm{g} / \mathrm{mL} \text { or } 50 \mu \mathrm{g} / \mathrm{mL}) \\
\text { prior to their incubation } \\
\text { with TNF superfamily } \\
\text { member } 14 \text { (TNFSF14), then } \\
\text { the IL-6 level in the culture } \\
\text { supernatants were } \\
\text { measured by ELISA. The } \\
\text { effects of TFDG, ECG, } \\
\text { EGCG, on MAPKs and } \\
\text { NF-kB pathways in } \\
\text { TNFSF14-stimulated HGFs } \\
\text { were measured using } \\
\text { Western blotting analysis. } \\
\text { The effect of TFDG, ECG, } \\
\text { EGCG, on TNFSF14 } \\
\text { receptor expression (HVEM } \\
\text { and LTbR) in HGFs were } \\
\text { measured using flow } \\
\text { cytometry. }\end{array}$ & $\begin{array}{l}\text { Using } 50 \mu \mathrm{g} / \mathrm{mL} \text { of TFDG, ECG, } \\
\text { or EGCG has significantly } \\
\text { lowered the IL-6 production in } \\
\text { TNFSF14-stimulated HGFs, } \\
\text { without harming cells. TFDG, } \\
\text { ECG or EGCG inhibited } \\
\text { TNFSF14-induced ERK, JNK, } \\
\text { and NF- } \mathrm{B} \text { activation and } \\
\text { suppressed TNFSF14 receptor } \\
\text { expression in HGFs. It is } \\
\text { supposed that TFDG, ECG or } \\
\text { EGCG suppressed IL-6 } \\
\text { production in } \\
\text { TNFSF14-stimulated HGFs } \\
\text { through the inhibition of JNK, } \\
\text { ERK, or NF- } k B \text { activation. }\end{array}$ & $\begin{array}{l}\text { Hosokawa et al., } \\
\text { 2010b }\end{array}$ & [36] \\
\hline $\begin{array}{l}\text { Type-A Cranberry } \\
\text { Proanthocyanidins } \\
\text { (AC-PAs) were isolated } \\
\text { from cranberries } \\
\text { (Vaccinium macrocarpon) }\end{array}$ & $\begin{array}{l}\text { Oral epithelial cells } \\
\text { (GMSM-K). }\end{array}$ & $\begin{array}{l}\text { Increasing concentrations } \\
\text { of AC-PAs ( } 25 \mu \mathrm{g} / \mathrm{mL} \text { to } \\
100 \mu \mathrm{g} / \mathrm{mL}) \text { were used to } \\
\text { pretreat epithelial cells } \\
\text { before their stimulation } \\
\text { with } P \text {. gingivalis. ELISA } \\
\text { kits were used to quantify } \\
\text { IL-6 and IL-8, CCL5 } \\
\text { concentrations in the } \\
\text { free-cell supernatants. } \\
\text { AC-PAs influence on NF- } \mathrm{B} \\
\text { p65 activation was } \\
\text { investigated. }\end{array}$ & $\begin{array}{l}\text { Type-A Cranberry } \\
\text { Proanthocyanidins have } \\
\text { significantly decreased the } \\
\text { secretion of IL- } 8 \text { and CCL5 at all } \\
\text { of the concentrations tested in a } \\
\text { dose-dependent manner, where } \\
100 \mu \mathrm{g} / \mathrm{mL} \text { dose has reduced } \\
\text { secretion of IL- } 8 \text { and CCL5 by } \\
\text { more than } 80 \% \text { and was not } \\
\text { related to loss of cell viability. } \\
\text { AC-PAs did not affect the } \\
\text { secretion of IL-6. } 50 \mu \mathrm{g} / \mathrm{mL} \text { of } \\
\text { AC-PAs significantly decreased } \\
\text { the P. gingivalis-induced activity } \\
\text { of NF-kB p65 from } 203.9 \% \\
\text { to } 91 \% \text {. }\end{array}$ & La et al., 2010 & [37] \\
\hline
\end{tabular}


Table 1. Cont.

\begin{tabular}{|c|c|c|c|c|c|}
\hline $\begin{array}{l}\text { Active Com- } \\
\text { pound/Extract/Fraction }\end{array}$ & Cells/Tissues & Methods & Results & Authors, Year & Ref. \\
\hline \multirow[t]{2}{*}{ Same as above } & \multirow[t]{2}{*}{$\begin{array}{l}\text { Human } \\
\text { monocyte-derived } \\
\text { macrophages. }\end{array}$} & $\begin{array}{l}\text { Investigate the effects of } \\
\text { Type-A cranberry PAs } \\
(25 \mu \mathrm{g} / \mathrm{mL}, 50 \mu \mathrm{g} / \mathrm{mL} \text {, and } \\
100 \mu \mathrm{g} / \mathrm{mL}) \text { on: } \\
\text { (1) } \text { The production of } \\
\text { various MMPs by } \\
\text { human } \\
\text { monocyte-derived } \\
\text { macrophages } \\
\text { stimulated with LPS } \\
\text { from } A \text {. actino- } \\
\text { mycetemcomitans by } \\
\text { using ELISA } \\
\text { combined with } \\
\text { piezoelectric printing } \\
\text { technology, } \\
\text { the catalytic activity } \\
\text { of recombinant } \\
\text { MMP-9 and } \\
\text { MMP-1, and } \\
\text { the expression of } 5 \\
\text { protein kinases and } \\
\text { the activity of NF- } \mathrm{kB} \\
\text { p65 in LPS stimulated } \\
\text { macrophages using } \\
\text { commercial kits. }\end{array}$ & \multirow[t]{2}{*}{$\begin{array}{l}\text { No toxic effects toward } \\
\text { macrophages were detected } \\
\text { following a } 24 \text { h treatment with } \\
\text { a } 100 \mu \mathrm{g} / \mathrm{mL} \text { of tested } \\
\text { proanthocyanidins. AC-PAs } \\
\text { significantly reduced the } \\
\text { production of MMP-7, MMP-8, } \\
\text { and MMP-13 in LPS stimulated } \\
\text { macrophages at all tested } \\
\text { concentrations, whereas } \\
\text { production of MMP-3 was } \\
\text { reduced significantly only at the } \\
\text { highest concentration } \\
\text { (100 } \mu \mathrm{g} / \mathrm{mL} \text { ) and production of } \\
\text { MMP-1, MMP-9 at } 50 \mu \mathrm{g} / \mathrm{mL} \text {. } \\
\text { AC-PAs also significantly } \\
\text { inhibited the catalytic activity of } \\
\text { MMP-1 and MMP-9. Inhibition } \\
\text { of MMP production was } \\
\text { associated with inhibition of the } \\
\text { NF- } k B \text { p65 activity and } \\
\text { decreased phosphorylation of } \\
\text { key intracellular kinases. }\end{array}$} & \multirow[t]{2}{*}{ La et al.,2009 } & \multirow[t]{2}{*}{ [38] } \\
\hline & & $\begin{array}{l}\text { Cytotoxicity was } \\
\text { determined using } \\
\text { MTT assay. }\end{array}$ & & & \\
\hline $\begin{array}{l}\text { Epigallocatechin-3- } \\
\text { gallate } \\
\text { (EGCG) }\end{array}$ & $\begin{array}{l}\text { MG-63, a human } \\
\text { osteosarcoma cell } \\
\text { line. }\end{array}$ & $\begin{array}{l}\text { MG-63 cells were incubated } \\
\text { with OSM (oncostatin M) } \\
\text { alone or together with } \\
10 \mu \mathrm{g} / \mathrm{mL} \text { EGCG (prior to } \\
\text { addition of OSM). The } \\
\text { levels of Cyr61 were } \\
\text { measured using Western } \\
\text { blot analysis. Moreover, } \\
\text { MG-63 cells were treatment } \\
\text { with Cyr61 and level of } \\
\text { CCL2 was measured with } \\
\text { an ELISA kit. }\end{array}$ & $\begin{array}{l}\text { OSM was found to stimulate } \\
\text { Cyr61 synthesis in MG- } 63 \text { cells } \\
\text { in a time dependent manner, } \\
\text { whereas EGCG has significantly } \\
\text { attenuated this effect. } \\
\text { Treatment of MG- } 63 \text { cells with } \\
\text { Cyr61 resulted in increased } \\
\text { release of CCL2. }\end{array}$ & Lee et al., 2009 & [39] \\
\hline $\begin{array}{l}\text { Apple condensed tannin } \\
\text { (ACT) isolated from } \\
\text { apple. Hop bract } \\
\text { polyphenols (HBP) } \\
\text { fraction rich in } \\
\text { proanthocyandins. } \\
\text { HMW-HBP (high } \\
\text { molecular weight } \\
\text { fraction) and LMW-HBP } \\
\text { (low molecular weight } \\
\text { fraction) separated from } \\
\text { HBP. Epigallocatechin-3- } \\
\text { gallate (EGCG) }\end{array}$ & $\begin{array}{l}\text { Human gingival } \\
\text { epithelial } \\
\text { (HGE) cells. }\end{array}$ & $\begin{array}{l}\text { HGE cells were stimulated } \\
\text { with } P \text {. gingivalis membrane } \\
\text { vesicles }(50 \mu \mathrm{g} / \mathrm{mL} \text { of final } \\
\text { concentration) in the } \\
\text { presence or absence of ACT, } \\
\text { HBP, HMW-HBP, } \\
\text { LMW-HBP, EGCG, or } 3 \\
\text { isolated compounds from } \\
\text { LMW-HBP: } \\
\text { 2-(2-methylpropanoyl)- } \\
\text { phloroglucinol } \\
\text { 1-O-b-D-glucopyranoside } \\
\text { (MPPG), isoquercitrin, and } \\
\text { astragalin at various } \\
\text { concentrations } \\
\text { (5-25 } \mu \mathrm{g} / \mathrm{mL}) \text { for } 24 \text { h. } \\
\text { PGE } 2 \text { secreted in the culture } \\
\text { supernatant was quantified } \\
\text { using an ELISA kit. }\end{array}$ & $\begin{array}{l}\text { The strongest, significantly } \\
\text { inhibition of PGE } 2 \text { production } \\
\text { was seen for EGCG, starting } \\
\text { from } 10 \mu \mathrm{g} / \mathrm{mL} \text {. ACT did not } \\
\text { influence on the PGE2 } \\
\text { production. HBP and } \\
\text { LMW-HBP significantly and } \\
\text { moderately inhibited the } \\
\text { production of PGE } \text { PG, similar like }_{\text {isolated from LMW-HBP }} \text { LM- } \\
\text { compounds: MPPG, } \\
\text { isoquercitrin, astragalin. }\end{array}$ & Inaba et al., 2008 & {$[40]$} \\
\hline
\end{tabular}


Table 1. Cont.

\begin{tabular}{|c|c|c|c|c|c|}
\hline $\begin{array}{l}\text { Active Com- } \\
\text { pound/Extract/Fraction }\end{array}$ & Cells/Tissues & Methods & Results & Authors, Year & Ref. \\
\hline $\begin{array}{l}\text { Fraction from } \\
\text { cranberries (Vaccinium } \\
\text { macrocarpon), obtained } \\
\text { after dialysis; } \\
\text { Non-dialysable } \\
\text { material (NDM) } \\
\text { contains } 65.1 \% \\
\text { proanthocyanidins }\end{array}$ & $\begin{array}{l}\text { Human gingival } \\
\text { fibroblasts } \\
\text { (HGF-1), U937 } \\
\text { human monocytes } \\
\text { differentiated to } \\
\text { macrophages. }\end{array}$ & $\begin{array}{l}\text { HGF-1 and } \\
\text { macrophages were } \\
\text { treated with the NDM } \\
\text { and then stimulated } \\
\text { with LPS from } A \text {. } \\
\text { actinomycetemcomitans. } \\
\text { MMP-9 and MMP-3 } \\
\text { production was } \\
\text { measured using ELISA } \\
\text { kits. Elastase, MMP-9 } \\
\text { and MMP-3 activities in } \\
\text { the presence of the } \\
\text { NDM were tested by } \\
\text { using colorimetric or } \\
\text { fluorogenic substrates. } \\
\text { The antibody } \\
\text { microarrays were used } \\
\text { to characterize changes } \\
\text { in the expression and } \\
\text { phosphorylation state of } \\
\text { fibroblast signaling } \\
\text { proteins. MTT assay was } \\
\text { used for evaluated cells } \\
\text { viability. }\end{array}$ & $\begin{array}{l}\text { Production of MMP-9 and } \\
\text { MMP-3 by LPS stimulated } \\
\text { macrophages pretreated } \\
\text { with the NDM were } \\
\text { inhibited significantly, in a } \\
\text { dose dependent manner, } \\
\text { similarly production of } \\
\text { MMP-3 by fibroblast. } \\
\text { However, MMP-9 response } \\
\text { in LPS stimulated fibroblast } \\
\text { wasn't observed. Cranberry } \\
\text { fraction wasn't toxic } \\
\text { towards fibroblast and } \\
\text { macrophages. NDM } \\
\text { revealed inhibitory effect on } \\
\text { some fibroblast intracellular } \\
\text { signaling proteins (Fos, JNK, } \\
\text { Jun, MKK3/6, MKK6, } \\
\text { Rac1/cdc42, and ROCK2). } \\
\text { Elastase, MMP-9 and } \\
\text { MMP-3 activities were } \\
\text { significantly inhibited by } \\
\text { NDM even at low } \\
\text { concentration-10 } 10 \text { /mL } \\
\text { (about } 50 \% \text { ). }\end{array}$ & $\begin{array}{l}\text { Bodet et al., } \\
2007\end{array}$ & [41] \\
\hline Same as above & $\begin{array}{l}\text { Human gingival } \\
\text { fibroblasts HGF-1. }\end{array}$ & $\begin{array}{l}\text { IL-6, IL-8, and PGE2 } \\
\text { production by } \\
\text { fibroblasts treated with } \\
\text { the NDM (10, } 25 \text { or } 50 \\
\mu \mathrm{g} / \mathrm{mL}) \text { and stimulated } \\
\text { by LPS from } A \text {. } \\
\text { actinomycetemcomitans } \\
\text { was evaluated by ELISA. } \\
\text { Changes in the } \\
\text { expression and } \\
\text { phosphorylation state of } \\
\text { fibroblast intracellular } \\
\text { signaling proteins were } \\
\text { characterized by } \\
\text { antibody microarrays. } \\
\text { Fibroblast viability was } \\
\text { evaluated using the } \\
\text { MTT assay. }\end{array}$ & $\begin{array}{l}\text { The production of PGE2, } \\
\text { IL- } 8 \text { and IL- } 6 \text { by LPS } \\
\text { stimulated fibroblasts was } \\
\text { inhibited by NDM at } \\
\text { non-toxic concentrations of } \\
10-50 \mu \mathrm{g} / \mathrm{mL} \text {. At a final } \\
\text { concentration of } 50 \mu \mathrm{g} / \mathrm{mL} \\
\text { cranberry fraction } \\
\text { completely inhibited the } \\
\text { IL- } 8 \text { production, whereas a } \\
72 \% \text { inhibition was noted at } \\
\text { a concentration of } 10 \\
\mu \mathrm{m} / \mathrm{mL} \text {. The PGE } 2 \text { and IL-6 } \\
\text { production was significantly } \\
\text { reduced in range } 25 \text { and } \\
50 \mu \mathrm{m} / \mathrm{mL} \text {. The results } \\
\text { suggest that the cranberry } \\
\text { fraction can act by reducing } \\
\text { the AP- } 1 \text { activity. NDM also } \\
\text { reduced expression } \\
\text { of COX-2. }\end{array}$ & $\begin{array}{l}\text { Bodet et al., } \\
2007\end{array}$ & [42] \\
\hline
\end{tabular}


Table 1. Cont.

\begin{tabular}{|c|c|c|c|c|c|}
\hline $\begin{array}{l}\text { Active Com- } \\
\text { pound/Extract/Fraction }\end{array}$ & Cells/Tissues & Methods & Results & Authors, Year & Ref. \\
\hline $\begin{array}{l}\text { Water-alcohol grape seed } \\
\text { extract (GSE) from red } \\
\text { grape seeds containing } \\
95 \% \text { oligomeric } \\
\text { proanthocyanidins (PAs), } \\
\text { gallic acid (GA), } \\
\text { epigallocatechin gallate } \\
\text { (EGCG) }\end{array}$ & $\begin{array}{l}\text { The murine } \\
\text { macrophages cell line } \\
\text { RAW 264.7. }\end{array}$ & $\begin{array}{l}\text { Cells were preincubated } \\
\text { with non-cytotoxic } \\
\text { concentrations of GA } \\
(4 \mu \mathrm{g} / \mathrm{mL}), \text { EGCG } \\
(0.5 \mu \mathrm{g} / \mathrm{mL}) \text { or GSE } \\
(4 \mu \mathrm{g} / \mathrm{mL}) \text { and stimulated } \\
\text { with LPS of } A \text {. } \\
\text { actinomycetemcomitans, } F \text {. } \\
\text { nucleatum. NO production } \\
\text { was quantified using the } \\
\text { colorimetric Griess assay, } \\
\text { iNOS expression was } \\
\text { evaluated using } \\
\text { immunoblotting, whereas } \\
\text { ROS production was } \\
\text { measured with the } \\
\text { fluorescent } \\
\text { 123-dihydrorhodamine dye. }\end{array}$ & $\begin{array}{l}\text { GSE as well EGCG strongly } \\
\text { decreased ROS and NO } \\
\text { production as well iNOS } \\
\text { expression in LPS-stimulated } \\
\text { macrophages. GA also showed } \\
\text { a strong inhibitory effect on NO } \\
\text { production; however, without } \\
\text { affecting iNOS expression and } \\
\text { slightly increasing ROS } \\
\text { production. }\end{array}$ & $\begin{array}{l}\text { Houde et al., } \\
2006\end{array}$ & [43] \\
\hline $\begin{array}{l}\text { EGCG } \\
(-) \text {-epigallocatechin } \\
\text { gallate }\end{array}$ & $\begin{array}{l}\text { Mouse calvarial } \\
\text { primary osteoblastic } \\
\text { cells. }\end{array}$ & $\begin{array}{l}\text { Mouse calvarial primary } \\
\text { osteoblastic cells were } \\
\text { pretreated with } \\
\text { epigallocatechin gallate } \\
(20 \mu \mathrm{M}) \text { in the presence of } \\
\text { sonicated Porphyromonas } \\
\text { gingivalis extracts. The } \\
\text { effect of epigallocatechin } \\
\text { gallate on the gene } \\
\text { expression of MMPs was } \\
\text { examined by RT-PCR. The } \\
\text { effect of EGCG on } \\
\text { osteoclast formation was } \\
\text { confirmed with TRAP } \\
\text { staining in a co-culture } \\
\text { system of mouse calvarial } \\
\text { primary osteoblastic cells } \\
\text { and bone marrow cells. }\end{array}$ & $\begin{array}{l}\text { P. gingivalis stimulated only the } \\
\text { expression of MMP- } 9 \text { mRNA } \\
\text { ( } 215 \% \text { increase) and this effect } \\
\text { was significantly reduced by } \\
\text { tested EGCG, reaching the level } \\
\text { of MMP-9 mRNA expression as } \\
\text { in untreated cells. Neither } P \text {. } \\
\text { gingivalis extracts nor EGCG } \\
\text { influenced the transcription } \\
\text { levels of MMP-2 and MMP-13. } \\
\text { Osteoclast formation was } \\
\text { significantly inhibited by EGCG } \\
\text { in the co-culture system. }\end{array}$ & Yun et al., 2004 & {$[44]$} \\
\hline $\begin{array}{l}\text { Fraction of green tea } \\
\text { polyphenols (GTP), } \\
\text { (-)epigallocatechin } \\
\text { gallate (EGCG), } \\
\text { (-)-epicatechin gallate } \\
\text { (ECG), } \\
\text { (-)-epigallocatechin } \\
\text { (EGC), (-)-epicatechin } \\
(\text { EC), (+)-catechin (C) }\end{array}$ & $\begin{array}{l}\text { Partially purified } \\
\text { MMP-12 from the } \\
\text { conditioned medium } \\
\text { of the mouse } \\
\text { macrophage cell line } \\
\text { NCTC } 3749 \text {, human } \\
\text { proMMP-2 and } \\
\text { mouse proMMP-9 } \\
\text { were activated with } \\
\text { APMA } \\
\text { (aminophenyl- } \\
\text { mercurin } \\
\text { acetate). }\end{array}$ & $\begin{array}{l}\text { GTP and } 5 \text { catechins were } \\
\text { tested for their ability to } \\
\text { inhibit MMP-12, MMP-9 } \\
\text { and (MMP)-2 activities } \\
\text { what was measured using } \\
\text { fluorimetry and with } \\
\text { gelatin or casein } \\
\text { zymography. In addition, } \\
\text { the activation of proMMP-2 } \\
\text { by the lectin concanavalin } \\
\text { A was determined after } \\
\text { GTP exposure. }\end{array}$ & $\begin{array}{l}\text { IC } 50 \text { values for the inhibition of } \\
\text { MMP- } 2 \text { and MMP- } 9 \text { activities } \\
\text { were } 10 \mu \mathrm{g} / \mathrm{mL} \text { and } 0.6 \mu \mathrm{g} / \mathrm{mL} \\
\text { for GTP, } 95 \mu \mathrm{M} \text { and } 28 \mu \mathrm{M} \text { for } \\
\text { ECG and } 6 \mu \mathrm{M} \text { and } 0.3 \mu \mathrm{M} \text { for } \\
\text { EGCG, respectively. MMP-12 } \\
\text { was inhibited by more than } 60 \% \\
\text { by } 1 \mu \mathrm{M} \text { of ECG or EGCG. } \\
\text { MMP-2, MMP-9 and MMP-12 } \\
\text { activities were unaffected by C, } \\
\text { EC, and EGC. MMP-2 } \\
\text { activation by concanavalin A } \\
\text { was reduced by } 50 \% \text { at } \\
17.5 \mu \mathrm{g} / \mathrm{mL} \text { of GTP and was } \\
\text { almost completely inhibited at } \\
35 \mu \mathrm{m} / \mathrm{mL} \text {. Among catechins (at } \\
100 \mu \mathrm{M} \text { ), only EGCG inhibited } \\
\text { the activation of MMP-2, The } \\
\text { activation of proMMP-2 was } \\
\text { inhibited in a dose-dependent } \\
\text { manner. The complete abolition } \\
\text { of the activation of pro-MMP-2 } \\
\text { (induced by Con A) was } \\
\text { recorded at } 25 \text { uM EGCG. }\end{array}$ & $\begin{array}{l}\text { Demeule et al., } \\
2000\end{array}$ & [45] \\
\hline
\end{tabular}


Table 1. Cont.

\begin{tabular}{|c|c|c|c|c|c|}
\hline $\begin{array}{l}\text { Active Com- } \\
\text { pound/Extract/Fraction }\end{array}$ & Cells/Tissues & Methods & Results & Authors, Year & Ref. \\
\hline $\begin{array}{l}\text { Elm extract (EE) } \\
\text { (n-butanol fraction from } \\
\text { extract of Ulmi macrocarpi } \\
\text { cortex) containing } 20 \% \text { of } \\
\text { procyanidins) and the } \\
\text { mixture of procyanidin } \\
\text { oligomers (PO) }\end{array}$ & $\begin{array}{l}\text { Gingival crevicular } \\
\text { fluid (GCF) collected } \\
\text { from periodontitis } \\
\text { patients; Cultures of } \\
\text { periodontal ligament } \\
\text { (PDL) cells treated } \\
\text { with Treponema } \\
\text { lecithinolyticum. }\end{array}$ & $\begin{array}{l}\text { The inhibitory effect of EE } \\
\text { and PO on the MMPs in } \\
\text { GCF (mostly MMP- } 8 \text { and } \\
\text { MMP-9) were assessed } \\
\text { using gelatin zymography. } \\
\text { The MMP-2 was verified by } \\
\text { immunoblotting. Effects of } \\
\text { EE and PO on cell } \\
\text { proliferation were tested } \\
\text { with MTT assay. }\end{array}$ & $\begin{array}{l}\text { EE and PO inhibited activity of } \\
\text { MMPs in GCF (the most } \\
\text { abundant in MMP- } 8 \text { and } \\
\text { MMP-9), as well pro and active } \\
\text { forms of MMP-2. PO was more } \\
\text { effective than the EE. The } \text { IC }_{50} \\
\text { values of the EE were } 29 \text { and } \\
45 \mu \mathrm{g} / \mathrm{mL} \text { for GCF collagenases } \\
\text { (mostly MMP- } 8 \text { and MMP-9 } \\
\text { detected in GCF) and MMP-2, } \\
\text { respectively. The corresponding } \\
\text { IC } 50 \text { values of the PO were } 25 \\
\text { and } 33 \mu \mathrm{m} / \mathrm{mL} \text {, respectively. } \\
\text { Contrary to PO, the EE extract } \\
\text { at concentrations of } 0.05-0.1 \% \\
\text { exhibited a cytotoxic effect } \\
\text { towards PDL cells. }\end{array}$ & Song et al., 2003 & [10] \\
\hline $\begin{array}{l}\text { Ethyl acetate fraction } \\
\text { from the tea leaf (Camellia } \\
\text { sinensis.) (+)-catechin (C), } \\
\text { (-)-epicatechin (EC), } \\
\text { (+)-gallocatechin (GC), } \\
\text { (-)-epigallocatechin } \\
\text { (EGC), (-)-epicatechin } \\
\text { gallate (ECg), } \\
\text { (-)-epigallocatechin } \\
\text { gallate (EGCG). }\end{array}$ & $\begin{array}{l}\text { Gingival crevicular } \\
\text { fluid (GCF) collected } \\
\text { from periodontitis } \\
\text { patients; purified } \\
\text { collagenase; in vitro } \\
\text { study. }\end{array}$ & $\begin{array}{l}\text { Ethyl acetate fraction and } 6 \\
\text { isolated catechins were } \\
\text { tested for their ability to } \\
\text { inhibit purified collagenase } \\
\text { activities using collagenase } \\
\text { of Clostridium histolyticum } \\
\text { and supernatant of } \\
\text { Porphyromonas gingivalis as } \\
\text { well collagenase activity in } \\
\text { GCF. Collagenase activity } \\
\text { was determined using a } \\
\text { commercially available kit. }\end{array}$ & $\begin{array}{l}\text { The complete inhibition of the } \\
\text { collagenase activity was } \\
\text { achieved by using a } 100 \mu \mathrm{g} / \mathrm{mL} \\
\text { of ethyl acetate fraction from } \\
\text { tea and } 50 \mu \mathrm{g} / \mathrm{mL} \text { ECG, EGCG. } \\
\text { Other catechins, without the } \\
\text { gallate residue had no effect on } \\
\text { collagenase. }\end{array}$ & $\begin{array}{l}\text { Makimura et al., } \\
1993\end{array}$ & [46] \\
\hline
\end{tabular}

Particularly, the $n$-butanol fraction from the Ulmus macrocarpa Hance bark, defined as elm extract (contain $20 \%$ of procyanidins) and the mixture of procyanidin oligomers (composed of 3 to 12 flavan-3-ol monomers, with average molecular weight of 1518) isolated from elm extract in range 100-1000 $\mu \mathrm{g} / \mathrm{mL}$ exhibited inhibitory effects on the MMPs, present in gingival crevicular fluid (GCF) of adult patients with periodontal disease (mainly, MMP-8 and MMP-9) and on the pro and active forms of MMP-2 (from the conditioned media of cultured periodontal ligament (PDL) cells treated with a periodontopathogen, Treponema lecithinolyticum) [10]. The inhibition of enzyme activity by procyanidin oligomers was more effective than by the elm extract, with IC50 values 25 and $33 \mu \mathrm{g} / \mathrm{mL}$ for GCF collagenases (mostly MMP-8 and MMP-9) and MMP-2, respectively. Moreover, elm extract and procyanidin oligomers inhibited proteolytic enzymes of two periopathogens, $T$. denticola, and $P$. gingivalis responsible for degradation of the interstitial and basement membrane collagens as well as activating of matrix metalloproteinases e.g., MMP-8, MMP-9 or MMP-1, MMP-3, and MMP-9 [10].

Free (non-polymerized) galloylated flavan-3-ols such as (-)-epicatechin gallate and (-)-epigallocatechin gallate (EGCG) from green tea also inhibited collagenase activity, achieved total inhibition at $50 \mu \mathrm{g} / \mathrm{mL}$ [46]. Other tested compounds, without the gallate residue such as catechin, epicatechin, gallocatechin, and epigallocatechin had no effect on collagenase. Makimura reported also that ethyl acetate fraction from tea leves (Camellia sinensis), which contained six above catechins inhibited collagenolytic proteases in gingival crevicular fluids (GCF) and in culture supernatants of Porphyromonas gingivalis [46]. Similar results were observed by Demeule et al. [45]. Green tea polyphenols, especially (-)-epigallocatechin gallate (EGCG) and (-)-epicatechin gallate (ECG), inhibited matrix metalloproteinase (MMP)-2, MMP-9, MMP-12 and proMMP-2 activities in the range of micromolar concentrations. In the following years, more studies confirmed the inhibitory effects of proanthocyanidins and its galloylated monomers on production and/or activity of matrix metalloproteinases MMPs (MMP-1, MMP-2, MMP-3, MMP-7, MMP-8, 
MMP-9, and MMP-13) involved in periodontitis (Table 1). Among them were proanthocyanidins and gallate catechins from green tea [21,44], theaflavins from black tea [20], A-type cranberry proanthocyanidins (AC-PAs) isolated from cranberries (Vaccinium macrocarpon fruits) $[28,31,32,38,41]$, proanthocyanidins from blueberries of two North American species-Vaccinium corymbosum [19], and V. angustifolium [22].

In opposition to the above results are results obtained by Lombarto et al. who showed [23] that AC-PAs and EGCG, individually or in combination, had no effect on the regulation of $\operatorname{MMP}(1,2,3,7,8,9,10,12$, and 13) and tissue inhibitors of metalloproteinases - TIMP $(1,2,3$, and 4$)$ secretion but inhibited the secretion of several cytokines in the (3D) co-culture model of gingival epithelial cells and fibroblasts stimulated with $A$. actinomycetemcomitans LPS (Table 1).

\subsection{Influence on Bone Tissue Resorption}

Yun et al. [44] reported an inhibitory effect of EGCG $(20 \mu \mathrm{M})$ on the MMP-9 gene expression in osteoblasts and on the formation of osteoclasts, which suggested that EGCG may prevent the alveolar bone resorption that occurs in periodontal diseases leading to teeth loss. Importantly, in the periodontal disease an enhanced osteoclastogenesis can occur due to the presence of the of inflammatory cytokines that stimulates osteoclast proliferation or promotes the differentiation of progenitor cells. Mature osteoclasts that derive from hematopoietic monocyte/macrophage precursors under the action of RANKL (receptor activator of NF- $\mathrm{KB}$ ligand) and M-CSF (macrophage colony-stimulating factor) mediate the destruction of the alveolar bone by attaching to the bone surface and promoting mineral dissolution. The demineralized bone matrix is later degraded by proteases such as cathepsin K and metalloproteinases (MMPs) [32]. Tanabe et al. [32] showed that ACPAs have influence the osteoclast formation and bone resorption activity. In a range of 10-100 $\mu \mathrm{g} / \mathrm{mL}$, AC-PAs inhibited RANKL-dependent osteoclast differentiation, as well as secretion of both MMP-2 and MMP-9 but secretion of IL- 8 was increased. IL- 8 from normal human bone marrow stromal cells inhibits the bone resorbing activity of osteoclasts [47].

Huang et al. [13] reported that proanthocyanidins (PA) may have an influence on the bone regeneration in the host inflammatory microenvironment by suppressing NF- $\mathrm{kB}$ signaling pathway and therefore may be a potential inducer of bone regeneration. In this study an effect of proanthocyanidins on osteogenic differentiation of human periodontal ligament fibroblasts (PDLFs) with or without TNF- $\alpha$ stimulation was tested and the biological mechanism was explored. The assumption was that periodontal ligament fibroblasts are capable of differentiating into osteoblasts, but pro-inflammatory cytokines like TNF- $\alpha$ inhibit this process. Osteogenic differentiation and mineralization associated markers were detected by qRT-PCR, alizarin red $S$ staining, and alkaline phosphatase (ALP) activity assay. In result, proanthocyanidins in low concentration $(0.1 \mu \mathrm{g} / \mathrm{mL}, 1 \mu \mathrm{g} / \mathrm{mL}$, $10 \mu \mathrm{g} / \mathrm{mL}$ ) significantly upregulated expression of osteogenesis-related genes and proteins and ALP activity in PDLFs compared with the control. However, proanthocyanidins at higher concentrations of $30 \mu \mathrm{g} / \mathrm{mL}$ and $50 \mu \mathrm{g} / \mathrm{mL}$ significantly suppressed the alkaline phosphatase activity of PDLFs. For the rest assay, authors used only lower concentration of PA $(0.1 \mu \mathrm{g} / \mathrm{mL}, 1 \mu \mathrm{g} / \mathrm{mL}, 10 \mu \mathrm{g} / \mathrm{mL})$. Proanthocyanidins in concentration of $1 \mu \mathrm{g} / \mathrm{mL}$ significantly reversed inhibition of osteogenesis related gene and protein expression, alkaline phosphatase activity, and mineralization caused by TNF- $\alpha$. The authors also suggested that proanthocyanidins may reverse TNF- $\alpha$ inhibited osteogenic differentiation via NF- $\kappa B$ signaling pathway. These authors used commercial proanthocyanidins claimed to possess an untypical for proanthocyanidins structure (Figure 3 ) and with molecular weight $=594.52$. The supplier's website states that proanthocyanidins have been isolated from grapes (the fruits of Vitis vinifera L.). 
<smiles>COC1Cc2c(O)cc(O)cc2OC1c1ccc(O)c(O)c1</smiles>

Figure 3. Structure of untypical proanthocyanidins isolated from fruits of Vitis vinifera used in the study of Huang et al. [13].

\subsection{Influence on Cytokines}

The overproduction and secretion of inflammatory cytokines by resident and immune cells modulate the progression and severity of periodontitis. Increase of such proinflammatory cytokines as: IL- $1 \alpha$, IL-1 $\beta$, TNF- $\alpha$, IL- 6 , and IL-17 were shown in patients with acute or chronic periodontitis [48]. More specifically, TNF $\alpha$ can be found at high levels in gingival crevicular fluid (GCF) and in diseased periodontal tissues, where it is positively correlated with MMPs and RANKL expression. Human and animal studies confirmed that TNF- $\alpha$ plays a central role in inflammatory reaction, alveolar bone resorption, and the loss of connective tissue attachment. Moreover, TNF- $\alpha$ up-regulates the production of other proinflammatory innate immunity cytokines, such as IL- $1 \beta$ and IL-6 associated with inflammatory cell migration and osteoclastogenesis [48]. IL-1 $\beta$ plays an important role in the pathogenesis of periodontitis also by regulation of the IL-6 production in a variety of cell types, including fibroblasts and epithelial cells [26]. Similar to bacterial LPS, cellular response to cytokines or chemokines (e.g., IL-1 $\beta$ ) can be mediated via signaling cascades, including NF- $\mathrm{KB}$ and MAPK/AP-1 pathways, which lead to gene expression of certain proteins (for example IL-6). There are more and more studies proving that proanthocyanidins and flavan-3-ols inhibit the secretion of cytokines by influencing NF- $\mathrm{kB}$ and MAPK/AP-1 activation (Table 1) [13,14,18-20,22,26,28,38].

Many studies have shown inhibition of production and/or secretion of inflammatory cytokines by proanthocyanidins. Bodet et al. [42] demonstrated that proanthocyanidinenriched cranberry fraction at concentrations $25-50 \mu \mathrm{g} / \mathrm{mL}$, significantly inhibited the IL-6, IL-8, and $\mathrm{PGE}_{2}$ production by gingival fibroblasts stimulated with the Aggregatibacter actinomycetemcomitans lipopolysaccharide (LPS). The most spectacular inhibitory effect was seen towards IL-8 that belongs to chemokines (CXCL8) also known as neutrophil chemotactic factor. It directs the migration of polymorphonuclear leukocytes, monocytes, and macrophages to the infection site. Increased level of IL- 8 was observed in the gingival crevicular fluid of inflamed periodontal sites [42]. $\mathrm{PGE}_{2}$ is another proinflammatory molecule involved in destructive process in periodontal disease. It is secreted in response to pro-inflammatory cytokines, periodontopathogens and LPS. The cranberry fraction significantly inhibited PGE2-response even at low tested concentration-25 $\mu \mathrm{g} / \mathrm{mL}$, and reduced COX-2 protein expression - the enzyme involved in PGE2 production. Moreover, cranberry fraction influence on the phosphorylation and expression of various intracellular proteins (Jun, Fos, MKK3, MKK6, Rac1, and Mnk1) which are implicated in cytokine production. Bodet et al. concluded that cranberry fraction may act especially via a downregulation of AP-1 activity [42]. Feldman and Grenier [31] showed an inhibitory effect of 25 or $50 \mu \mathrm{g} / \mathrm{mL}$ of A-type cranberry proanthocyanidins (APA) on TNF- $\alpha$, IL-6, and IL-8 secretion in a macrophage model. The $50 \mu \mathrm{g} / \mathrm{mL}$ concentration of APA reduced the LPSinduced secretion of TNF- $\alpha$, IL- 6 and IL- 8 , by about $50 \%$, but had not influence on IL- $1 \beta$. A significant reduction in IL- $1 \beta$ secretion was seen when ACPA was used together with licochalcone A (chalcone, not proanthocyanidin). Further studies on proanthocyanidins, in the predominant amount on A-type cranberry proanthocyanidins, prove their influence on 
the secretion and production of interleukins, as well as provided explanation of molecular mechanisms responsible for this activity [12,17,23,26-29,37] (Table 1).

Galarraga-Vinueza et al. [12] revealed that cranberry concentrate from capsules (Uriach-Aquilea OTC, Barcelona, Spain) containing $130 \mathrm{mg}$ A-type PAs significantly decreased M1 polarization and increased M2 polarization in LPS-stimulated macrophages. M1 phenotype of macrophage are activated by bacteria sub-products like lipopolysaccharide and are associated with the secretion of pro-inflammatory cytokines (such as IL-1 $\beta$, IL-6, IL-8), whereas a M2 phenotype of macrophages are activated by alternative ways and are associated with the secretion of anti-inflammatory cytokines (such as IL-10) and growth factors which enhance tissue regeneration. Galarraga-Vinueza et al. [12] confirmed the effect of A-type PAs (50 and $100 \mu \mathrm{g} / \mathrm{mL}$ ) on cytokine expression-proinflammatory cytokines: IL-8 and IL-6 were significantly downregulated in LPS-stimulated macrophages and A-type PAs, whereas an anti-inflammatory IL-10 was upregulated. No influence on expression of IL-1ß was seen. Lagha et al. [17] showed that fraction of proanthocyanidins (PAs) from cranberries at a concentration of $15.625-125 \mu \mathrm{g} / \mathrm{mL}$ markedly reduced cytotoxicity of leukotoxin on macrophages and significantly reduced (by about $80-90 \%$ at 15.625 and more than $98 \%$ at $125 \mu \mathrm{g} / \mathrm{mL}$ ) release of caspase- 1 , IL- $1 \beta$, and IL-18 from LtxA-induced macrophages. Leukotoxin (LtxA), released by A. actinomycetemcomitans is an important virulence factor playing a critical role in the pathogenic process of localized aggressive periodontitis (LAP). LtxA affects immune cells by activates pyroptosis of monocytes and macrophages and inducing the release of pro-inflammatory cytokines. Pyroptosis is the inflammatory form of programmed cell death, involves the activation of caspase-1, which in turn coverts of pro-IL-1 $\beta$ and pro-IL-18 to the biologically active forms. In macrophages, pyroptosis leads to the formation of pores in the plasma membrane which allows secretion of IL-1 $\beta$ and IL-18, cytokines known as damage-associated molecular patterns (DAMPs) and contribute to the progression of periodontitis by increasing cell migration and osteoclastogenesis [49,50]. Moreover, PAs reduced the expression of CIAS and P2X7 genes (increase by LtxA, in macrophages) by about $30-45 \%$, similarly for a range $15.625-125 \mu \mathrm{g} / \mathrm{mL}$ [17]. This is important because the P2X7 receptor activation and CIAS activation leads to the rapid formation of membrane pores and to the release of IL- $1 \beta$ and IL-18. Moreover, the cranberry proanthocyanidins blocked the binding of LtxA to macrophages and reduced ROS and superoxide production in LtxA-induced macrophages.

Cranberry proanthocyanidins (PAs) can differently affect interleukins secretion/production, depending on a cell type. In lipopolysaccharide-stimulated normal human gingival fibroblast, cranberry non-dialyzable material (NDM) rich in proanthocyanidins decreased level of IL-6, what is consistent with other studies, but NDM significantly increased IL-6 in lipopolysaccharide-stimulated human gingival fibroblast cells from a patient suffering from aggressive form periodontitis (AgP fibroblasts) [28]. This increasing level of IL-6 occurred only in the presence of LPS; NDM alone did not show a significant increase in production of IL-6. Simultaneously, NDM inhibited NF- $\mathrm{KB}$ activity (increased by LPS treatment) in AgP fibroblasts hinting at the involvement of other molecular mechanisms of IL-6 regulation in these cells.

Influence of proanthocyanidins and flavan-3-ols from other source than cranberries on the secretion and production of interleukins was also demonstrated in several studies (Table 1). Jekabsone et al. [15] reported that Pelargonium sidoides root extract (PSRE) and especially proanthocyanidin fraction from PSRE (PACN) exhibits a strong, antibacterial properties (against Aggregatibacter actinomycetemcomitans), anti-inflammatory and gingival tissue protecting properties under periodontitis-mimicking conditions. The cells (gingival fibroblast, bone marrow-derived macrophages (BMDM) or human peripheral blood mononuclear cells (PBMCs) were stimulated using lipopolysaccharide (and IFN $\gamma$ for BMDM) and treated with $50 \mu \mathrm{g} / \mathrm{mL}$ and $100 \mu \mathrm{g} / \mathrm{mL}$ of PSRE or PACN. The extracts protected human gingival fibroblast from $A$. actinomycetemcomitans infection, decreased lipopolysaccharide-induced release of IL-8 and prostaglandin E2 from gingival fibroblasts and IL- 6 from leukocytes, blocked expression IL-1 $\beta$, iNOS and COX-2 but not TNF- $\alpha$. 
Stronger anti-inflammatory activity of proanthocyanidin fraction (PACN) than root extract (PSRE) was associated with higher amounts of prodelphinidins. The study also reported that PSRE and PACN $(100 \mu \mathrm{g} / \mathrm{mL})$ blocked the surface presentation of CD80 and CD86 (surface markers of proinflammatory M1 phenotype) in LPS + IFN $\gamma$-treated macrophages, whereas PACN was characterized by stronger activity. These results indicate that both PACN and PSRE are potent in preventing macrophage conversion to proinflammatory M1 phenotype under exposure to LPS.

Low concentrations (7.9-62.5 $\mu \mathrm{g} / \mathrm{mL})$ extracts from a black and green tea as well as their flavan-3-ols (epigallocatechin-3-gallate, theaflavins) have influence on production and secretion proinflammatory cytokines. They reduce the epithelial gingival barrier dysfunction caused by TNF- $\alpha$ and modulate the hosts inflammatory response. They inhibited the activation of NF- $\mathrm{KB}$ and caspase- 1 as well as reduced IL-1 $\beta$ secretion by macrophages (at $62.5 \mu \mathrm{g} / \mathrm{mL}$ by more than $94 \%$, except black tea-64.5\%), and secretion IL-8 (only black tea required higher concentration than $62.5 \mu \mathrm{g} / \mathrm{mL}$ for more than $70 \%$ inhibition) by human oral epithelial cells stimulated with recombinant TNF- $\alpha$ [16]. The green tea extract showed higher activity than black tea extract. Other studies have confirmed the inhibitory effect of tea derived flavan-3-ols on the secretion of pro-inflammatory cytokines from LPS stimulated macrophages as well from cytokines-stimulated gingival cells (Table 1) [14,23,24,36]. Ben Lagha et al. [20] presented consistent results in which they proved inhibitory effect theaflavins (TFs) from black tea on the secretion of pro-inflammatory cytokines from Porphyromonas gingivalis treated macrophages and on the activation of the NF- $\mathrm{KB}$ signaling pathway (Table 1). Lombardo Bedran et al. [24,25] in studies on green and black tea and their main galloylated flavan-3-ols revealed the ability of these compounds to induce human beta-defensin (hBD) secretion in gingival epithelial cells. HBDs are antimicrobial peptides secreted by gingival epithelium in response to periopathogens. HBDs interact with the bacterial cell membrane, and lead to pore formation and finally to the lysis of major periopathogens. Evidence indicated that level of hBDs is higher in healthy gingival tissues than in periodontal gingival tissues and that some periopathogens like P. gingivalis, are capable to down-regulate hBD expression by epithelial cells and/or to inactivate hBDs by the means of the proteolytic cleavage [25]. Both green and black teas and their galloylated flavan-3-ols stimulated secretion of hBDs and increased expression of the $h B D$ gene in gingival epithelial cells as well as prevented the degradation of hBD1 and hBD2 by periopatogen $P$. gingivalis. Again, the tested non-galloylated flavan-3-ols-theaflavins failed to induce secretion of significant amounts of hBDs by the epithelial cells.

In addition to the inhibitory effect of EGCG on innate immune response (e.g., IL1, IL-6, TNF- $\alpha$ ), an influence on adaptive immunity mechanisms (Th1, Th2, Th17, and Tregs) was demonstrated. Hosokawa et al. [30] showed influence of EGCG on Th2-type chemokines, such as CCL11 production. The EGCG in range 3.125-50 $\mu \mathrm{g} / \mathrm{mL}$ decreased CCL11 production in IL-1 $\beta /$ IL-4 or TNF- $\alpha /$ IL-4-stimulated human gingival fibroblasts (HGFs) in a concentration dependent manner (almost total reduction at $50 \mu \mathrm{g} / \mathrm{mL}$ ). Moreover, they demonstrated that ERK and JNK activations, related to CCL11 production in HGFs, are inhibited by EGCG treatment. The same group demonstrated an inhibitory effect of EGCG and ECG on CXC chemokine ligand 10 (CXCL10 production (about 60\% inhibition by $50 \mu \mathrm{g} / \mathrm{mL}$ ) in human gingival fibroblasts (HGFs) stimulated oncostatin M (OSM) - cytokine belonging to the interleukin family [35]. CXCL10 is a Th1-type chemokine which plays a key role in the recruitment of Th1 cells, and thus in the development of periodontal disease. It is supposed that EGCG and ECG suppressed production of CXCL10 through the inhibition of phosphorylation of signal transduction molecules like JNK, Akt and STAT3 phosphorylation as well as by suppressed OSMR $\beta$ expression in stimulated HGFs [35]. Influence on adaptive immunity mechanisms was also proved for cranberry ACPAs [37]. AC-PAs significantly decreased the secretion of C-C motif ligand 5 (CCL5) from P. gingivalis-stimulated oral epithelial cells $(100 \mu \mathrm{g} / \mathrm{mL}$ of AC-PAs reduced secretion of CCL5 and also IL- 8 by more than $80 \%$ ). The CCL5 chemokine (has significant chemotactic activity for Th1 cells as well basophiles, eosinophiles, monocytes [37]. 
In addition to the above, there is a couple of other well studied sources of proanthocyanidins with proven anti-inflammatory activities linked with periodontitis.

Castanopsis lamontii water extract (CLE), $(400 \mu \mathrm{g} / \mathrm{mL})$ rich in epicatechin (EC) and procyanidin B2 (PB2) as well as EC (120 $\mu \mathrm{g} / \mathrm{mL})$ and PB2 $(34.4 \mu \mathrm{g} / \mathrm{mL})$ alone, has suppressed in a significant manner the lipopolysaccharide-stimulated inflammation by inactivating the TLR-4/NF- $\mathrm{kB} / \mathrm{iNOS}$ and TLR-4/NF- $\mathrm{kB} / \mathrm{COX}-2$ pathways [18]. All tested samples (CLE, EC, PB2) decreased the release of NO, PGE2, and TNF- $\alpha$ from stimulated-LPS mouse macrophage RAW264.7. PB2 appeared to be much more potent in suppressing the lipopolysaccharide-stimulated inflammatory response than EC.

Ben Lagha et al. [19] proved inhibitory effect of proanthocyanidins isolated from highbush blueberry (Vaccinium corymbosum) on the secretion of pro-inflammatory cytokines from LPS-Aggregatibacter actinomycetemcomitans treated macrophages and on the activation of the NF- $\mathrm{KB}$ signaling pathway. PAs at $125 \mu \mathrm{g} / \mathrm{mL}$ reduced the secretion of IL- $1 \beta$, TNF- $\alpha$, IL-6, and CXCL8 by $75.34 \%, 81.64 \%, 48.27 \%$, and $90.19 \%$, respectively [19]. Similarly, promising results were reported in the study on ethanolic lowbush blueberry extract (Vaccinium angustifolium) [22]. A pre-treatment of macrophages with the blueberry extract (in concentration of $62.5 \mu \mathrm{g} / \mathrm{mL}$ ) and then stimulation with Fusobacterium nucleatum inhibited the secretion of IL- $1 \beta$, TNF- $\alpha$, and IL- 6 by $87.3 \%, 80.7 \%$, and $28.2 \%$, respectively. The secretion of the chemokine CXCL8 was affected by $500 \mu \mathrm{g} / \mathrm{mL}, 250 \mu \mathrm{g} / \mathrm{mL}$, or $125 \mu \mathrm{g} / \mathrm{mL}$ extract, decreased CXCL8 secretion by $79 \%, 57.9 \%$, and $11.2 \%$ respectively [22].

Proanthocanydin- enriched extract from Myrothamnus flabellifolia, plants traditionally used for treatment of gingival inflammation and periodontitis in South Africa, decreased gene expression of IL-1 $\beta$, IL- 8 and TNF- $\alpha$, and level of IL-6 in KB cells, pre-incubated with MF $(10 \mu \mathrm{g} / \mathrm{mL}$ and $100 \mu \mathrm{g} / \mathrm{mL})$ and infected with Porphyromonas gingivalis [33].

\subsection{Influence on Reactive Oxygen Species (ROS)}

ROS and reactive nitrogen species (RNS) production by immune cells stimulated by periopathogens is an important factor in pathogenesis of periodontitis [43]. Their overproduction can lead to oxidative damage to healthy gingival tissue, periodontal ligament, and alveolar bone. Study of Houde et al. [43] showed that the stimulation of macrophages with lipopolysaccharide from Aggregatibacter. actinomycetemcomitans and Fusobacterium nucleatum induces increased NO and ROS release. However, macrophages pretreated with non-cytotoxic concentrations of grape seed extract (GSE) containing 95\% oligomeric proanthocyanidins significantly inhibited free radical generation by inhibiting the production of the proinflammatory mediators NO and ROS and by modulating iNOS protein expression. Significant decrease of ROS (e.g., superoxide) production by macrophages (exposed to LtxA) was also observed in the presence of cranberry PAs [17]. The addition of $125 \mu \mathrm{g} / \mathrm{mL}$ of PAs reduced ROS and superoxide production by $92.2 \%$ and $72.7 \%$, respectively. These outcomes are supported by the results from animal studies [51], [52], further discussed below.

\section{In Vivo Studies Reporting Influence Proanthocyanidins or Flavan-3-ols on Periodontitis in Animal Models}

Among the reviewed studies, eleven reported the influence of proanthocyanidins or flavan-3-ols on periodontitis in animal models. Three of them used grape seed proanthocyanidin extract [52-54]; four used the flavan-3-ols [14,39,55,56]; two used green tea extract [57,58]; finally, one study used cranberry (Vaccinium macrocarpon) juice [29] and one unverified commercial proanthocyanidin (PA) [51]. Toker et al. [53] presented results which indicated that grape seed proanthocyanidin extract (GSPE) can substantially decrease periodontal tissue inflammatory process and alveolar bone loss by decreasing MMP- 8 and hypoxia-inducible factor 1-alpha (HIF-1- $\alpha$ ) levels and increase osteoblast activity in diabetic rats with experimentally induced periodontal disease (Table 2). Giving $100 \mathrm{mg} / \mathrm{kg}$ and $200 \mathrm{mg} / \mathrm{kg}$ doses of grape seed proanthocyanidin extract (GSPE) administered by oral gavage to rats with induced diabetes and periodontitis significantly decreased alveolar bone loss, inflammatory cell numbers, MMP- 8 and HIF-1- $\alpha$ levels compared to rats with 
diabetes + periodontitis but without GSPE. Moreover, the osteoblast number increased significantly in the GSPE groups compared to the periodontitis and diabetes + periodontitis groups. Oral administration of commercial grape seed proanthocyanidins (PC) [52] to rats with experimentally induced periodontitis (EP) revealed that PC enhanced the host resistance and inhibited the oxidative stress. In serum, proanthocyanidins (PC) significantly decreased reactive oxygen species, lipid peroxides, lysosomal enzymes, acute phase proteins and they increased antioxidant levels. Histopathological evidence of experimentally induced periodontitis without PC showed cellular infiltration of inflammatory cells whereas the groups treated with proanthocyanidins demonstrated only scattered inflammatory cells. Similar anti-inflammatory effect of grape seed extract (GSE) was observed in Ozden et al. study [54].

Cai et al. [55] study indicated that EGCG alleviates P. gingivalis induced periodontitis in the animal model. The mice orally inoculated with P. gingivalis in PBS, received sterile food and drunk water with $0.02 \%$ epigallocatechin-3-gallate solution in the period from 8 weeks to 15 weeks. It was found that epigallocatechin-3-gallate has significantly reduced alveolar bone resorption as well as decreased the high expressions (caused by P. gingivalis infection) of inflammatory cytokines and other mediators both in serum and in gingival tissue (details in the Table 2) what is consistent with a previous study of Lee y et al. [39], in which epigallocatechin-3-gallate showed a suppressing effect one the progression of periodontitis, by diminishing Cyr61 expression (a potential osteolytic mediator) in osteoblast cells and, subsequently, macrophage chemotaxis into the lesions. Cho et al. [56] observed decreased IL-6 and TNF expression in the tissue of rats orally fed EGCG compared to the group without EGCG. Downregulation of TNF- $\alpha$ and IL-6 expression by EGCG led to a decrease of the number of osteoclast number as well as decrease in their activity, which finally has resulted lower bone loss. They also noticed reduced collagen destruction in EGCG group. Similar results achieved Lee at al. [14] studying catechin, another of major flavan-3-ols in green tea. They showed that catechin has reduced the level of bone loss in mouse animal model with a P. gingivalis induced periodontitis. 
Table 2. In vivo studies reporting influence proanthocyanidins or flavan-3-ols on periodontitis in animal model.

\begin{tabular}{|c|c|c|c|c|c|}
\hline $\begin{array}{l}\text { Active Com- } \\
\text { pound/Extract/Fraction }\end{array}$ & Animal Model & Methods & Results & Authors, Year & Ref. \\
\hline Catechin & $\begin{array}{l}\text { Six-week-old C57BL } \\
\text { laboratory mice were } \\
\text { divided into } 4 \text { equal } \\
\text { groups: } \\
\text { (a) } \begin{array}{l}\text { untreated } \\
\text { normal control } \\
\text { group; } \\
\text { (b) } \begin{array}{l}\text { Porphyromonas } \\
\text { gingivalis } \\
\text { infected group }\end{array} \\
\text { (c) } \begin{array}{l}\text { Porphyromonas } \\
\text { gingivalis }\end{array} \\
\text { infected + } \\
\text { catechin group, } \\
\text { only catechin } \\
\text { treated group. }\end{array}\end{array}$ & $\begin{array}{l}\text { Catechin ( } 40 \mathrm{mg} / \mathrm{kg} \text { body } \\
\text { weight) was administrated } \\
\text { orally to the animals } 30 \mathrm{~min} \\
\text { before the Porphyromonas } \\
\text { gingivalis injection, for two } \\
\text { weeks, and subsequently } \\
\text { every two days for an } \\
\text { additional two more weeks. } \\
\text { The animals were sacrificed } \\
\text { after } 49 \text { days from the } \\
\text { beginning of the study. } \\
\text { Quantitative analysis of } \\
\text { alveolar bone loss was } \\
\text { performed using a } \\
\text { microcomputed } \\
\text { tomography. }\end{array}$ & $\begin{array}{l}\text { The bone loss area was } \\
\text { reduced significantly in } \\
\text { the Porphyromonas } \\
\text { gingivalis+catechin } \\
\text { group (c), compared to } \\
\text { the periodontitis group } \\
\text { (b). }\end{array}$ & Lee et al., 2020 & [14] \\
\hline $\begin{array}{l}\text { Water extract of Japanese } \\
\text { green tea }\end{array}$ & $\begin{array}{l}\text { 8-week male } \\
\text { C57BL } / 6 \text { mice. } \\
10 \text { groups ( } n=6 \text { each) } \\
\text { including control } \\
\text { group with distilled } \\
\text { water and } \\
9 \text { experimental } \\
\text { groups with distilled } \\
\text { water or different } \\
\text { concentrations of } \\
\text { Japanese green tea. }\end{array}$ & $\begin{array}{l}\text { Animals had an } \\
\text { inflammation induced by } \\
\text { placing a silk thread } \\
\text { ligature around maxillary } \\
\text { molar for } 7 \text { days to } \\
\text { accumulate plaque. } \\
\text { Different concentrations } \\
(1.5 \mathrm{~g}, 3 \mathrm{~g} \text {, and } 6 \mathrm{~g} \text { dried tea } \\
\text { leaves per } 60 \mathrm{~mL} \text { of water) } \\
\text { of Japanese green tea were } \\
\text { used for watering the } \\
\text { animals for } 1-3 \text { weeks after } \\
\text { ligature removal. The tea } \\
\text { infusion was obtained by } \\
\text { putting the leaves for } 90 \mathrm{~s} \\
\text { in a } 70^{\circ} \mathrm{C} \text { water. Mice were } \\
\text { sacrificed after the end of } \\
\text { experiment. } \\
\text { Histopathological analysis } \\
\text { was performed, and } \\
\text { Micro-CT were done for a } \\
\text { vertical alveolar bone loss } \\
\text { measurement. }\end{array}$ & $\begin{array}{l}\text { Green tea significant } \\
\text { inhibited } \\
\text { ligature-induced bone } \\
\text { loss. Moreover, it has } \\
\text { alleviated the number } \\
\text { of inflammatory cells } \\
\text { and osteoclasts. The } \\
\text { effect of green tea } \\
\text { extract was found to be } \\
\text { concentration and time } \\
\text { dependent. The most } \\
\text { significant therapeutic } \\
\text { effect was obtained } \\
\text { with } 6 \text { g/ } 60 \text { mL green } \\
\text { tea at } 1 \text { week of } \\
\text { administration. }\end{array}$ & Kaboosaya et al., 2020 & [57] \\
\hline $\begin{array}{l}\text { Unverified commercial } \\
\text { proanthocyanidin (PA) } \\
\text { purchased at Sigma } \\
\text { Chemical Co., St. Louis, } \\
\text { MO, USA. }\end{array}$ & $\begin{array}{l}\text { Male Wistar rats } \\
\text { were divided into } 3 \\
\text { groups: Group 1: } \\
\text { Control Group 2: } \\
\text { Rats with } \\
\text { experimental } \\
\text { periodontitis (EP), } \\
\text { divided next to } \\
\text { Group 3: } 6 \text { rats with } \\
\text { experimental } \\
\text { periodontitis (EP) } \\
\text { received } 30 \mathrm{mg} \text { PA } \\
\text { (subcutaneously) } / \mathrm{kg} \\
\text { body weight for } 30 \\
\text { days; and Group } 4: 6 \\
\text { rats with } \\
\text { experimental } \\
\text { periodontitis (EP) } \\
\text { received } 20 \text { mg } \\
\text { tinidazole } \\
\text { (administered } \\
\text { orally)/kg body } \\
\text { weight for } 30 \text { days. }\end{array}$ & $\begin{array}{l}\text { Experimental periodontitis } \\
\text { was induced by injecting } E \text {. } \\
\text { coli endotoxin. After the } \\
\text { treatment procedure, the } \\
\text { animals were sacrificed and } \\
\text { blood was collected to } \\
\text { perform biochemical assays: } \\
\text { hydrogen peroxide }\left(\mathrm{H}_{2} \mathrm{O}_{2}\right) \text {, } \\
\text { superoxide anion }\left(\mathrm{O}_{2}{ }^{-}-\right), \\
\text {myeloperoxidase (MPO), } \\
\text { lipid peroxides, fibrinogen } \\
\text { assay, C-reactive protein } \\
(\mathrm{CRP}), \text { ascorbic acid, } \\
\alpha \text {-tocopherol, } \\
\text { ceruloplasmin, reduced } \\
\text { glutathione. Moreover, the } \\
\text { animal maxilla halves were } \\
\text { dissected, and they were } \\
\text { analyzed using light } \\
\text { microscopy. }\end{array}$ & $\begin{array}{l}\text { Proanthocyanidins and } \\
\text { tinidazole significant } \\
\text { inhibition of reactive } \\
\text { oxygen species and } \\
\text { lipid peroxides. In } \\
\text { group with PA (3) and } \\
\text { tinidazole (4) } \\
\text { significant decrease in } \\
\text { the levels of acute } \\
\text { phase proteins was } \\
\text { observed compare to } \\
\text { EP group (2). Moreover, } \\
\text { PA (3) and tinidazole } \\
\text { (4) significant increased } \\
\text { levels of nonenzymatic } \\
\text { antioxidants. Contrary } \\
\text { to the EP group (2), no } \\
\text { cellular infiltration of } \\
\text { inflammatory cells was } \\
\text { observed } \\
\text { in the PA and tinidazole } \\
\text { groups in histopathologica } \\
\text { examination. }\end{array}$ & Govindaraj et al., 2019 & [51] \\
\hline
\end{tabular}


Table 2. Cont.

\begin{tabular}{|c|c|c|c|c|c|}
\hline $\begin{array}{l}\text { Active Com- } \\
\text { pound/Extract/Fraction }\end{array}$ & Animal Model & Methods & Results & Authors, Year & Ref. \\
\hline $\begin{array}{l}\text { A commercial grape seed } \\
\text { proanthocyanidin extract } \\
\text { (GSPE) containing } 50 \mathrm{mg} \\
\text { polyphenols and } 30 \mathrm{mg} \\
\text { flavonoids in } 100 \mathrm{mg}\end{array}$ & $\begin{array}{l}\text { Animal study, } 40 \\
\text { Wistar male rats were } \\
\text { used: } \\
\text { C group-Control } \\
\text { group, } \\
\text { P } \\
\text { group_-Periodontitis } \\
\text { group, } \\
\text { D group-Diabetes } \\
\text { group, } \\
\text { D+P } \\
\text { group-Diabetes and } \\
\text { periodontitis group, } \\
\text { GSPE-100 } \\
\text { group-Diabetes, } \\
\text { periodontitis and } 100 \\
\text { mg/kg/day GSPE } \\
\text { group, } \\
\text { GSPE-200 } \\
\text { group-Diabetes, } \\
\text { periodontitis and } 200 \\
\text { mg/kg/day GSPE } \\
\text { group. }\end{array}$ & $\begin{array}{l}\text { GSPE were administered by } \\
\text { oral gavage. The animals } \\
\text { were sacrificed after } 30 \\
\text { days. Alveolar bone loss } \\
\text { was measured with a } \\
\text { stereomicroscope. Level of } \\
\text { (MMP)-8, VEGF and } \\
\text { HIF-1alpha was defined } \\
\text { with } \\
\text { immunohistochemistry. } \\
\text { Tartrate-resistant acid } \\
\text { phosphatase-positive } \\
\text { osteoclast cells were also } \\
\text { determined. Total } \\
\text { inflammatory cells } \\
\text { (eosinophil, lymphocyte, } \\
\text { neutrophil, and } \\
\text { macrophage cells) in an } \\
\text { area of } 10,000 \mu \mathrm{m}^{2} \text { of } \\
\text { periodontal ligament were } \\
\text { counted. }\end{array}$ & $\begin{array}{l}\text { The highest alveolar } \\
\text { bone loss was observed } \\
\text { in the group with } \\
\text { induced diabetes }+ \\
\text { periodontitis (D+P) } \\
(p<0.05) \text {. GSP-200 } \\
\text { group significantly } \\
\text { decreased alveolar } \\
\text { bone loss ( } p<0.05) \text {. In } \\
\text { the D+P highest } \\
\text { osteoclast count was } \\
\text { found however the } \\
\text { difference was not } \\
\text { significant compared to } \\
\text { the P, GSPE-100 and } \\
\text { GSPE-200 groups. } \\
\text { GSPE-100 and } \\
\text { GSPE-200 groups } \\
\text { significantly decreased } \\
\text { inflammatory cell } \\
\text { numbers compare to } \\
\text { D+P group. The } \\
\text { osteoblast numbers } \\
\text { increased in the } \\
\text { GSPE-100 and } \\
\text { GSPE-200 groups } \\
\text { compared to the P and } \\
\text { D+P groups ( } p<0.05) \text {. } \\
\text { MMP-8 and HIF-1alpha } \\
\text { levels were highest in } \\
\text { the D+P group and } \\
\text { GSPE significantly } \\
\text { decreased these levels } \\
\text { ( } p<0.05) \text {. }\end{array}$ & Toker et al., 2018 & [53] \\
\hline $\begin{array}{l}\text { Grape seed extract (GSE) } \\
\text { was obtained from } \\
\text { Berkem SA, (Gardonne, } \\
\text { France), and supplied in } \\
\text { a form of standardized } \\
\text { extract containing }>90 \% \\
\text { oligomeric } \\
\text { proanthocyanidins }\end{array}$ & $\begin{array}{l}40 \text { male Sprague } \\
\text { Dawley rats. } 4 \text { equal } \\
\text { groups were used. } \\
\text { Group A was a } \\
\text { positive control, the } \\
\text { rats were fed only } \\
\text { standard laboratory } \\
\text { diet/water; Groups } \\
\text { B, C, D experimental } \\
\text { group rats that } \\
\text { received GSE (same } \\
\text { dose) for different } \\
\text { periods of time. } \\
\text { Group B-received } \\
\text { GSE for two weeks } \\
\text { before periodontitis } \\
\text { induction and } \\
\text { continued for six } \\
\text { weeks; Group } \\
\text { C-received GSE } \\
\text { from the day of } \\
\text { periodontitis } \\
\text { induction and } \\
\text { continued for six } \\
\text { weeks. Group } \\
\text { D-received GSE } \\
\text { after ligature removal } \\
\text { and continued for } \\
\text { two weeks. }\end{array}$ & $\begin{array}{l}\text { Animals had an } \\
\text { inflammation induced by } \\
\text { placing a } 4-0 \text { suture around } \\
\text { mandibular molar. Sutures } \\
\text { were kept for } 4 \text { weeks to } \\
\text { induce periodontitis. GSE } \\
\text { was systemically } \\
\text { administered via gavage } \\
\text { feeding every single a day } \\
\text { in a dose of } 200 \mathrm{mg} / \mathrm{kg} \\
\text { body weight. After animals } \\
\text { were sacrificed, histological } \\
\text { and immunohistochemical } \\
\text { examination of the } \\
\text { specimens were carried out. }\end{array}$ & $\begin{array}{l}\text { The anti- } \\
\text { inflammatory activity } \\
\text { of the GSE was } \\
\text { observed. } \\
\text { Inflammatory cell } \\
\text { number (ICN) was } \\
\text { lower in the } \\
\text { experimental groups } \\
\text { with GSE. Clinical } \\
\text { attachment level (CAL) } \\
\text { was higher in } \\
\text { experimental GSE } \\
\text { groups. Osteoclast } \\
\text { density (OD) was lower } \\
\text { in experimental GSE } \\
\text { groups compared to the } \\
\text { control. In the gingival } \\
\text { epithelium (GE) more } \\
\text { IL-10 accumulation was } \\
\text { determined in } \\
\text { experimental groups } \\
\text { compared to the } \\
\text { control. No difference } \\
\text { in TGF- } \beta \text { in GE was } \\
\text { found between the } \\
\text { groups. }\end{array}$ & Özden et al., 2017 & {$[54]$} \\
\hline
\end{tabular}


Table 2. Cont.

\begin{tabular}{|c|c|c|c|c|c|}
\hline $\begin{array}{l}\text { Active Com- } \\
\text { pound/Extract/Fraction }\end{array}$ & Animal Model & Methods & Results & Authors, Year & Ref. \\
\hline $\begin{array}{l}\text { Epigallocatechin-3- } \\
\text { gallate } \\
\text { (EGCG) }\end{array}$ & $\begin{array}{l}\text { Animal study: } 24 \\
\text { female mice were } \\
\text { divided into } 3 \text { equal } \\
\text { groups. The mice } \\
\text { received distilled } \\
\text { water: groups (1) and } \\
\text { (2) distilled water or } \\
0.02 \% \text { solution of } \\
\text { EGCG (group 3) from } \\
8 \text { weeks to } 15 \text { weeks. }\end{array}$ & $\begin{array}{l}\text { Mice were orally inoculated } \\
\text { with (1) PBS or } \\
\text { Porphyromonas gingivalis in } \\
\text { PBS - groups (2) and (3). At } \\
\text { the age of } 15 \text { weeks, the } \\
\text { mice were euthanized to } \\
\text { collect blood, gingival } \\
\text { tissue and maxillae samples. } \\
\text { Mouse inflammation } \\
\text { antibody array C1 was used } \\
\text { to detect the intensities of } \\
40 \text { mouse inflammatory } \\
\text { mediators in serum. } \\
\text { Cytokine levels were } \\
\text { detected using ELISA kits } \\
\text { for IL-17 and IL-1ß in } \\
\text { serum. The sections of } \\
\text { gingival tissue were } \\
\text { visualized with IL-17 and } \\
\text { IL-1 } \beta \text { specific } \\
\text { immunostaining. } \\
\text { The level of gene expression } \\
\text { in the gingival tissue was } \\
\text { determined using RT-qPCR. } \\
\text { Alveolar bone resorption } \\
\text { was analyzed by forming } \\
\text { three dimensional } \\
\text { structures using a } \\
\text { microcomputed } \\
\text { tomography. }\end{array}$ & $\begin{array}{l}\text { EGCG significantly } \\
\text { reduced P. gingivalis } \\
\text { induced alveolar bone } \\
\text { resorption. } \\
\text { In serum sample, } \\
\text { EGCG significantly } \\
\text { decreased the high } \\
\text { expressions (caused by } \\
\text { P. gingivalis infection) of } \\
\text { proteins such as: IL-1 } \beta \text {, } \\
\text { IL-6, IL-9 and IL-12p70, } \\
\text { exotain-1, exotain-2, fas } \\
\text { ligand, MCP-1, MIG, } \\
\text { MIP-1 } \alpha, \text { whereas IL-17 } \\
\text { and TNF- } \alpha \text { were } \\
\text { slightly decreased } \\
\text { without being } \\
\text { statistically significant. } \\
\text { ELISA assay showed } \\
\text { that EGCG reduced } \\
\text { level of IL-17 and IL-1 } \beta \\
\text { in serum, however } \\
\text { IL-17 level was not } \\
\text { statistically significant. } \\
\text { In the gingival tissue, } \\
\text { EGCG reduced, } \\
\text { increased by } P . \\
\text { gingivalis infection, } \\
\text { expression of IL-17 and } \\
\text { IL-1 } \beta \text { as well as } \\
\text { significantly } \\
\text { down-regulated the } \\
\text { level of gene } \\
\text { expression: IL-1 } \beta, \text { IL-6, } \\
\text { TNF- } \alpha, \text { RANKL, CCL2 } \\
\text { and MMP-9, but not } \\
\text { IL-23. The expression } \\
\text { of IL-17 and MMP-2 } \\
\text { were slightly } \\
\text { down-regulated but } \\
\text { without statistically } \\
\text { significant. }\end{array}$ & Cai et al., 2015 & [55] \\
\hline
\end{tabular}


Table 2. Cont.

\begin{tabular}{|c|c|c|c|c|c|}
\hline $\begin{array}{l}\text { Active Com- } \\
\text { pound/Extract/Fraction }\end{array}$ & Animal Model & Methods & Results & Authors, Year & Ref. \\
\hline $\begin{array}{l}\text { Non-dialyzable material } \\
\text { (NDM) prepared from } \\
\text { concentrated cranberry } \\
\text { (Vaccinium macrocarpon) } \\
\text { juice, rich in } \\
\text { proanthocyanidins }\end{array}$ & $\begin{array}{l}\text { Female BALB } / \mathrm{c} \\
\text { mice. }\end{array}$ & $\begin{array}{l}\text { Mice }(n=16) \text { were oral } \\
\text { infected with } \\
\text { Porphyromonas gingivalis } \\
\text { and Fusobacterium } \\
\text { nucleatum mixture (1:1). } \\
\text { NDM ( } 4 \text { mg/mL) was } \\
\text { added to the bacteria (in } \\
\text { PBS) and the drinking } \\
\text { water, whereas the control } \\
\text { group received the infection } \\
\text { in PBS alone. The maxillary } \\
\text { jaws were harvested, and } \\
\text { alveolar bone loss was } \\
\text { evaluated by computed } \\
\text { microtomography. Mice }(n \\
=12) \text { were challenged by an } \\
\text { injection of PBS containing } \\
\text { a mixture of } P . \text { gingivalis } \\
\text { and } F \text {. nucleatum into the } \\
\text { chambers of dorsolumbar } \\
\text { area. In the experimental } \\
\text { groups, NDM was added to } \\
\text { the bacteria (in PBS) or to } \\
\text { the PBS at a final } \\
\text { concentration of } 4 \text { mg/mL, } \\
\text { whereas the control group } \\
\text { received the infection in } \\
\text { PBS alone. Chamber } \\
\text { exudates were harvested } \\
\text { for analysis-TNF- } \alpha \text {, } \\
\text { quantified using two-site } \\
\text { ELISA. }\end{array}$ & $\begin{array}{l}\text { The NDM addition to } \\
\text { the mixed infection } \\
\text { reduced the alveolar } \\
\text { bone loss induced by } \\
\text { the mixed infection by } \\
\text { approximately } 20 \% \text {. In } \\
\text { subcutaneous chamber } \\
\text { model of inflammation, } \\
\text { the addition of NDM } \\
\text { resulted in reduced of } \\
\text { TNF- } \alpha \text { levels, } \\
\text { compared with group } \\
\text { without NDM, at all } \\
\text { tested times, however } \\
\text { results were statistically } \\
\text { significant only at } 24 \mathrm{~h} \\
\text { post-infection, but not } \\
\text { at } 2 \mathrm{~h} \text {. }\end{array}$ & Polak et al., 2013 & [29] \\
\hline $\begin{array}{l}\text { Epigallocatechin-3- } \\
\text { gallate } \\
\text { (EGCG) }\end{array}$ & 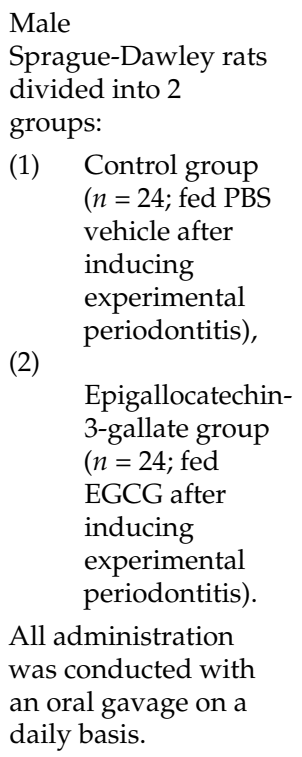 & $\begin{array}{l}\text { Animals sacrificed 1, } 2 \text { and } \\
4 \text { weeks after EGCG or PBS } \\
\text { administration. } \\
\text { Histomorphometric and } \\
\text { histologic analyses, tartrate } \\
\text { resistant acid phosphatase } \\
\text { staining and } \\
\text { immunohistochemistry } \\
\text { were carried out. }\end{array}$ & $\begin{array}{l}\text { Administration of } \\
\text { EGCG decreased the } \\
\text { expression of IL-6 } \\
\text { already in the early } \\
\text { treatment period and } \\
\text { decreased the } \\
\text { expression of TNF at } \\
\text { the } 4 \text { th week of } \\
\text { treatment. } \\
\text { Downregulation of } \\
\text { TNF and IL-6 } \\
\text { expression by EGCG } \\
\text { led to a reduction in the } \\
\text { number and activity of } \\
\text { osteoclasts, resulting in } \\
\text { reduced bone loss. } \\
\text { EGCG also reduced } \\
\text { collagen destruction. }\end{array}$ & Cho et al., 2013 & [56] \\
\hline
\end{tabular}


Table 2. Cont.

\begin{tabular}{|c|c|c|c|c|c|}
\hline $\begin{array}{l}\text { Active Com- } \\
\text { pound/Extract/Fraction }\end{array}$ & Animal Model & Methods & Results & Authors, Year & Ref. \\
\hline $\begin{array}{l}\text { Commercial grape seed } \\
\text { extract containing } 95 \% \\
\text { proanthocyanidins (PA) }\end{array}$ & $\begin{array}{l}\text { Male Wistar with } \\
\text { experimentally } \\
\text { induced periodontitis } \\
\text { (by injecting E. coli } \\
\text { endotoxin). The } \\
\text { experimental group } \\
\text { was divided into } \\
\text { subgroups } \\
\text { depending on the } \\
\text { dose of subcutaneous } \\
\text { proanthocyjanidin } \\
\text { used ( } 10-40 \mathrm{mg} / \mathrm{kg} \\
\text { body weight) and } \\
\text { treatment time (10-30 } \\
\text { days of treatment). } \\
\text { One subgroup was } \\
\text { treated with } \\
\text { metronidazole } \\
\text { (20 mg / kg body } \\
\text { weight) for } 30 \text { days } \\
\text { (administered orally). }\end{array}$ & $\begin{array}{l}\text { After the experimental } \\
\text { period, the rats were } \\
\text { euthanized to collect blood, } \\
\text { bone and teeth. Bone and } \\
\text { teeth were obtained for the } \\
\text { histopathological } \\
\text { evaluation. }\end{array}$ & $\begin{array}{l}\text { PA at an effective dose } \\
\text { of } 30 \mathrm{mg} / \mathrm{kg} \text { body } \\
\text { weight when } \\
\text { administered } \\
\text { subcutaneously, for } 30 \\
\text { days caused a decrease } \\
\text { in serum lipid } \\
\text { peroxides, reactive } \\
\text { oxygen species, } \\
\text { lysosomal enzymes, } \\
\text { acute phase proteins, } \\
\text { and an increase in } \\
\text { antioxidant levels. } \\
\text { Histopathological } \\
\text { evidence of } \\
\text { experimental } \\
\text { periodontitis showed } \\
\text { cellular infiltration of } \\
\text { inflammatory cells } \\
\text { while PA treated } \\
\text { groups demonstrated } \\
\text { only scattered } \\
\text { inflammatory cells. }\end{array}$ & Govindaraj et al., 2010 & [52] \\
\hline $\begin{array}{l}\text { Epigallocatechin-3- } \\
\text { gallate } \\
\text { (EGCG) }\end{array}$ & $\begin{array}{l}20 \text { Wistar rats } \\
\text { divided into } 2 \text { equal } \\
\text { groups: Animals } \\
\text { were given } \\
\text { intraperitoneal } \\
\text { injections EGCG ( } 80 \\
\mathrm{mg} / \mathrm{kg} \text { ) or were } \\
\text { given intraperitoneal } \\
\text { injections of normal } \\
\text { saline (NS, as control) } \\
\text { on a daily basis until } \\
\text { death. The animals } \\
\text { were sacrificed after } \\
20 \text { days. }\end{array}$ & $\begin{array}{l}\text { The jaws were dissected, } \\
\text { and radiographs were } \\
\text { taken. Cyr61 and CCL2 } \\
\text { were measured using } \\
\text { immunohistochemistry } \\
\text { assays. }\end{array}$ & $\begin{array}{l}\text { Administration of EGCG } \\
\text { has significantly } \\
\text { impaired a periapical } \\
\text { bone resorption } \\
\text { compared with the } \\
\text { control. Moreover, the } \\
\text { image analysis showed } \\
\text { that EGCG suppressed } \\
\text { periapical osteolysis by } \\
\text { an average of } 57.2 \% \text {. } \\
\text { EGCG diminished Cyr61 } \\
\text { expression in osteoblast } \\
\text { cells and, subsequently, } \\
\text { macrophage chemotaxis } \\
\text { into the lesions. A lower } \\
\text { percentage of } \\
\text { Cyr61-positive } \\
\text { osteoblasts in the } \\
\text { EGCG-treated group } \\
\text { (21.3\%), compared with } \\
\text { that in the control group } \\
\text { (62.1\%) was observed. }\end{array}$ & Lee et al., 2009 & [39] \\
\hline $\begin{array}{l}\text { Extract from the leaf of } \\
\text { Camelia sinensis, } \\
\text { containing } 41.6 \% \\
\text { catechins }\end{array}$ & $\begin{array}{l}29 \text { cats (mongrel; } \\
\text { male } 15 \text {, female 14) } \\
\text { affected with } \\
\text { gingivitis. }\end{array}$ & $\begin{array}{l}\text { Cats were fed the } \\
\text { commercial control diet for } \\
14 \text { days, prior to being put } \\
\text { on the experimental diet for } \\
45 \text { days. The experimental } \\
\text { diet with extract }(0.4 \mathrm{mg} / \mathrm{g} \\
\text { or } 0.8 \mathrm{mg} / \mathrm{g} \text { ) was prepared } \\
\text { for the animals. Cats were } \\
\text { fed twice daily during the } \\
\text { test period. Gingival index } \\
\text { (GI), oral malodor, and } \\
\text { percentage of the genus } \\
\text { Porphyromonas in the } \\
\text { subgingival microbiota } \\
\text { were examined. }\end{array}$ & $\begin{array}{l}\text { Addition of } \\
\text { catechin-rich extract } \\
\text { resulted in a significant } \\
\text { decrease in gingival } \\
\text { index (more marked for } \\
0.8 \mathrm{mg} / \mathrm{g} \text { than } \\
0.4 \mathrm{mg} / \mathrm{g} \text { ) and decrease } \\
\text { the odor from the mouth, } \\
\text { but significant only for } \\
\text { diet with } 0.8 \mathrm{mg} / \mathrm{g} \\
\text { extract. The experimental } \\
\text { diet also caused a } \\
\text { significant decrease in } \\
\text { the percentage of } \\
\text { Porphyromonas sp. } \\
\text { (stronger for } 0.8 \mathrm{mg} / \mathrm{g} \\
\text { than } 0.4 \mathrm{mg} / \mathrm{g} \text { ). }\end{array}$ & Isogai et al., 2008 & [58] \\
\hline
\end{tabular}

In turn, Polak et al. [29] showed that cranberry non-dialyzable material (NDM) consumption by mice infected by $P$. gingivalis and F. nucleatum has lowered the alveolar bone 
loss compared to the mice with infection but without NDM treatment. Moreover, in subcutaneous chamber model of inflammation, NDM alone has been shown to reduce TNF- $\alpha$ levels induced by the mixed infection. In vivo studies were supported by in vitro study (Table 1).

\section{Clinical Studies}

Until this moment, only three studies have been published pertaining to the use of proanthocyanidins or flavan-3-ols in periodontal disease in humans [59-61]. Two of them relate to the use of local delivery drug therapy with green tea extracts. Specifically, a thermo-reversible sustained-release system with incorporated green tea extract and hydroxypropylcellulose strips containing green tea catechin were used. Local therapeutic systems turned out to be effective in reducing periodontal pockets and inflammation [60,61] (details in Table 3). However, the weakness of Hirsawa et al. study [61] was the limited number of subjects in experimental group, as only 6 patients were treated. Díaz Sánchez et al. [59] were the only one to design study using pills rich in oligomeric proanthocyanidins. In this clinical study, 10 of 20 healthy volunteers with an induced gingivitis took the experimental treatment with oligomeric proanthocyanidins supplement administered orally as a dissoluble pill. According to Diaz Sánchez et al., the supplement caused improvement in the periodontal tissues condition during the period of treatment [59]. Although this study does not refer to periodontitis but to reversible gingivitis, the positive effect of the use oligomeric proanthocyanidins draws attention and encourages further clinical research.

Table 3. Clinical studies.

\begin{tabular}{|c|c|c|c|c|c|}
\hline Treatment & $\begin{array}{l}\text { Study Design and } \\
\text { Population }\end{array}$ & Methods & Results & Authors, Year & Ref. \\
\hline $\begin{array}{l}\text { The experimental } \\
\text { treatment consisted } \\
\text { of } 90 \mathrm{mg} \text { supplement } \\
\text { based on blueberry } \\
\text { and red fruit rich in } \\
\text { oligomeric } \\
\text { proanthocyanidins } \\
\text { (OPCs) (equivalent to } \\
36 \mathrm{mg} \\
\text { OPCs-oligomeric } \\
\text { proanthocyanidins) } \\
\text { and } 120 \mathrm{mg} \text { of } \\
\text { vitamin C }\end{array}$ & $\begin{array}{l}\text { A prospective, } \\
\text { double-blind, randomized, } \\
\text { controlled clinical trial in } \\
\text { the gingivitis prevention. } \\
20 \text { healthy volunteers took } \\
\text { the experimental or placebo } \\
\text { treatment for } 21 \text { days. The } \\
\text { pill was maintained in the } \\
\text { mouth until complete } \\
\text { dissolution. }\end{array}$ & $\begin{array}{l}\text { Two evaluation visits } \\
\text { were } \\
\text { performed-after } 14 \\
\text { and } 21 \text { days. During } \\
\text { clinical examination } \\
\text { Silness and Löe } \\
\text { index, the gingival } \\
\text { bleeding index, the } \\
\text { Turesky plaque index, } \\
\text { the inflammatory } \\
\text { crevicular fluid study } \\
\text { (IL6), and changes in } \\
\text { the brightness of the } \\
\text { gingiva were } \\
\text { evaluated. }\end{array}$ & $\begin{array}{l}\text { The Silness and Löe } \\
\text { gingival index was higher } \\
\text { in the control group than in } \\
\text { the experimental group. } \\
\text { The bleeding was lower in } \\
\text { the experimental group } \\
\text { compared to the control } \\
\text { group. In contrast to the } \\
\text { above results, the amount } \\
\text { of dental plaque was } \\
\text { slightly higher (33\%) in the } \\
\text { experimental group versus } \\
\text { in the control group. No } \\
\text { significant differences } \\
\text { between the study group } \\
\text { and the control group were } \\
\text { seen in brightness of the } \\
\text { gingiva. Statistically } \\
\text { significant differences in } \\
\text { level of IL-6 were found at } \\
\text { the baseline between the } \\
\text { experimental group and the } \\
\text { control group and in the } \\
\text { subsequent visits. However, } \\
\text { in experimental group level } \\
\text { of IL-6 was lower. }\end{array}$ & $\begin{array}{l}\text { Díaz Sánchez et al., } \\
2017\end{array}$ & [59] \\
\hline
\end{tabular}


Table 3. Cont.

\begin{tabular}{|c|c|c|c|c|c|}
\hline Treatment & $\begin{array}{l}\text { Study Design and } \\
\text { Population }\end{array}$ & Methods & Results & Authors, Year & Ref. \\
\hline $\begin{array}{l}\text { Thermo-reversible } \\
\text { sustained-release } \\
\text { system incorporated } \\
\text { with green tea extract }\end{array}$ & $\begin{array}{l}\text { A controlled, split-mouth } \\
\text { single-evaluator masked } \\
\text { study was conducted to } \\
\text { evaluate the effect of green } \\
\text { tea extract as a } \\
\text { sustained-release system in } \\
\text { patients with chronic } \\
\text { periodontitis (CP). } 30 \\
\text { patients, each with } 2 \text { sites } \\
\text { (test and control) having } \\
\text { probing depths (PDs) of } \geq 4 \\
\text { mm, were selected. Green } \\
\text { tea and placebo gels were } \\
\text { placed at test and control } \\
\text { sites as an adjunct to Phase } \\
1 \text { periodontal therapy. }\end{array}$ & $\begin{array}{l}\text { Assessment of } \\
\text { gingival index (GI), } \\
\text { pocket depth (PD), } \\
\text { and relative clinical } \\
\text { attachment levels } \\
\text { (rCALs) was done at } \\
\text { baseline and at } \\
4 \text { weeks. }\end{array}$ & $\begin{array}{l}\text { When the comparison of } \\
\text { means of GI, PD, and rCAL } \\
\text { was done between baseline } \\
\text { values and at the end of } \\
4 \text { weeks within the test } \\
\text { group, and control group } \\
\text { all the parameters were } \\
\text { lowered and statistically } \\
\text { highly significant. The test } \\
\text { group showed significantly } \\
\text { better results when } \\
\text { compared with controls. } \\
\text { Adjunctive local drug } \\
\text { therapy with } \\
\text { thermo-reversible green tea } \\
\text { gel has revealed to reduce } \\
\text { pockets and inflammation } \\
\text { during the } 4 \text { weeks of the } \\
\text { clinical trial in } \\
\text { patients with CP. }\end{array}$ & Chava and Vedula 2013 & {$[60]$} \\
\hline
\end{tabular}

6 volunteers with advanced periodontitis, but with no other systemic disorders. From each volunteer two pockets were selected: one for administration of the test agent and the other for

Hydroxypropylcellulose placebo. Strips were strips containing applied in pockets in green tea catechin (Taiyo Kagaku, Mie, patients once a week for 8 weeks.

Yokkaichi, Japan)

The subjects were divided randomly into the scaled group (3 subjects) non-scaled group (3 subjects) were applied in pockets in patients.

The clinical PD, enzymatic (peptidase activities) and microbiological effects (the proportion of black-pigmented, Gram-negative anaerobic rods (BPR) of the catechin) were determined.
The PD and the BPR were decreased in the catechin group with mechanical treatment at week 8 compared to baseline. The peptidase activities in the gingival fluid were maintained at lower levels during the experimental period in the test sites with catechin, while it reached $70 \%$ of that at baseline in the placebo sites.

\section{Conclusions}

Among the numerous in vitro studies (36) on the immunomodulatory effect of proanthocyanidins or flavan-3-ols on the host cells, most concern the tea leaves extract and its compounds- catechins with presence of the galloyl moiety as the most active, as well as of A-type proanthocyanidins from fruits of Vaccinium species. Other sources of proanthocyanidins such as grape seeds and traditional medicinal plants, were seldom. The in vitro studies proved their immunomodulatory activity, among others by influencing on immune cell regulation, proinflammatory cytokines synthesis and gene expression as well as by radical scavenging and inhibition of certain enzymes. They modulate NF- $\mathrm{B}$ (nuclear factor kappa-light-chain-enhancer of activated B cells) and mitogen-activated protein kinase (MAPK) pathways. Despite these promising results there is still much less studies using animal models (11) and only a few clinical studies (3). In conclusion, the potential of flavan-3-ols and their derivatives in prevention and alleviation of periodontitis is remarkable but clinical evidence is urgently needed for issuing credible dietary recommendation and complementary treatments.

Author Contributions: Conceptualization, I.N.-H., P.K.-R., and J.H.; methodology, I.N.-H., P.K.-R. and J.H.; software, I.N.-H and J.H.; validation, I.N.-H. and A.M.; formal analysis, I.N.-H., J.H.; investigation, I.N.-H., A.M., P.K.-R., and J.H.; resources, I.N.-H., A.M., P.K.-R., and J.H.; data curation, 
I.N.-H., P.K.-R., and J.H.; writing-original draft preparation, I.N.-H., J.H., and P.K.-R.; writingreview and editing, I.N.-H. and A.M.; visualization, I.N.-H., and J.H.; supervision, I.N.-H., A.M. and J.H.; project administration, I.N.-H.; All authors have read and agreed to the published version of the manuscript.

Funding: I.N.-H.'s and J.H.'s research received support from WMU young investigators grants NO. STM.D030.20.009 and STM.B040.20.076, respectively.

Institutional Review Board Statement: Not applicable.

Informed Consent Statement: Not applicable.

Data Availability Statement: Not applicable.

Conflicts of Interest: The authors declare no conflict of interest.

\section{References}

1. Nawrot-Hadzik, I.; Matkowski, A.; Dobrowolska-Czopor, B.; Olchowy, C.; Dominiak, M.; Kubasiewicz-Ross, P. Proanthocyanidins and Flavan-3-ols in the Prevention and Treatment of Periodontitis-Antibacterial Effects. Nutrients 2021, 13, 165. [CrossRef] [PubMed]

2. Cecoro, G.; Annunziata, M.; Iuorio, M.T.; Nastri, L.; Guida, L. Periodontitis, low-grade inflammation and systemic health: A scoping review. Medicina 2020, 56, 272. [CrossRef] [PubMed]

3. Slots, J. Periodontitis: Facts, fallacies and the future. Periodontol. 2000 2017, 75, 7-23. [CrossRef] [PubMed]

4. Madianos, P.N.; Bobetsis, Y.A.; Kinane, D.F. Generation of inflammatory stimuli: How bacteria set up inflammatory responses in the gingiva. J. Clin. Periodontol. 2005, 32 (Suppl. 6), 57-71. [CrossRef]

5. Yahfoufi, N.; Alsadi, N.; Jambi, M.; Matar, C. The immunomodulatory and anti-inflammatory role of polyphenols. Nutrients 2018, 10, 1618. [CrossRef]

6. Verma, R.P.; Hansch, C. Matrix metalloproteinases (MMPs): Chemical-biological functions and (Q)SARs. Bioorg. Med. Chem. 2007, 15, 2223-2268. [CrossRef]

7. Sorsa, T.; Tjäderhane, L.; Salo, T. Matrix metalloproteinases (MMPs) in oral diseases. Oral Dis. 2004, 10, 311-318. [CrossRef]

8. Feghali, K.; Feldman, M.; La, V.D.; Santos, J.; Grenier, D. Cranberry proanthocyanidins: Natural weapons against periodontal diseases. J. Agric. Food Chem. 2012, 60, 5728-5735. [CrossRef]

9. Birkedal-Hansen, H. Role of Matrix Metalloproteinases in Human Periodontal Diseases. J. Periodontol. 1993, 64 (Suppl. 5S), 474-484.

10. Song, S.-E.; Choi, B.-K.; Kim, S.-N.; Yoo, Y.-J.; Kim, M.-M.; Park, S.-K.; Roh, S.-S.; Kim, C.-K. Inhibitory effect of procyanidin oligomer from elm cortex on the matrix metalloproteinases and proteases of periodontopathogens. J. Periodontal Res. 2003, 38, 282-289. [CrossRef]

11. Nissinen, L.; Kähäri, V.M. Matrix metalloproteinases in inflammation. Biochim. Biophys. Acta Gen. Subj. 2014, 1840, 2571-2580. [CrossRef] [PubMed]

12. Galarraga-Vinueza, M.E.; Dohle, E.; Ramanauskaite, A.; Al-Maawi, S.; Obreja, K.; Magini, R.; Sader, R.; Ghanaati, S.; Schwarz, F. Anti-inflammatory and macrophage polarization effects of Cranberry Proanthocyanidins (PACs) for periodontal and peri-implant disease therapy. J. Periodontal Res. 2020, 55, 821-829. [CrossRef] [PubMed]

13. Huang, J.; Liu, L.; Jin, S.; Zhang, Y.; Zhang, L.; Li, S.; Song, A.; Yang, P. Proanthocyanidins Promote Osteogenic Differentiation of Human Periodontal Ligament Fibroblasts in Inflammatory Environment Via Suppressing NF- $\kappa$ B Signal Pathway. Inflammation 2020, 43, 892-902. [CrossRef] [PubMed]

14. Lee, H.A.; Song, Y.R.; Park, M.H.; Chung, H.-Y.; Na, H.S.; Chung, J. Catechin ameliorates Porphyromonas gingivalis-induced inflammation via the regulation of TLR2/4 and inflammasome signaling. J. Periodontol. 2020, 91, 661-670. [CrossRef] [PubMed]

15. Jekabsone, A.; Sile, I.; Cochis, A.; Makrecka-Kuka, M.; Laucaityte, G.; Makarova, E.; Rimondini, L.; Bernotiene, R.; Raudone, L.; Vedlugaite, E.; et al. Investigation of Antibacterial and Antiinflammatory Activities of Proanthocyanidins from Pelargonium sidoides DC Root Extract. Nutrients 2019, 11, 2829. [CrossRef]

16. Ben Lagha, A.; Grenier, D. Tea polyphenols protect gingival keratinocytes against TNF- $\alpha$-induced tight junction barrier dysfunction and attenuate the inflammatory response of monocytes/macrophages. Cytokine 2019, 115, 64-75. [CrossRef]

17. Ben Lagha, A.; Howell, A.; Grenier, D. Cranberry Proanthocyanidins Neutralize the Effects of Aggregatibacter actinomycetemcomitans Leukotoxin. Toxins 2019, 11, 662. [CrossRef]

18. Gao, Y.; Zhang, X.; Yin, J.; Du, Q.; Tu, Y.; Shi, J.; Xu, Y. Castanopsis lamontii Water Extract Shows Potential in Suppressing Pathogens, Lipopolysaccharide-Induced Inflammation and Oxidative Stress-Induced Cell Injury. Molecules 2019, $24,273$. [CrossRef]

19. Ben Lagha, A.; LeBel, G.; Grenier, D. Dual action of highbush blueberry proanthocyanidins on Aggregatibacter actinomycetemcomitans and the host inflammatory response. BMC Complement. Altern. Med. 2018, 18, 10. [CrossRef]

20. Ben Lagha, A.; Grenier, D. Black tea theaflavins attenuate Porphyromonas gingivalis virulence properties, modulate gingival keratinocyte tight junction integrity and exert anti-inflammatory activity. J. Periodontal Res. 2017, 52, 458-470. [CrossRef] 
21. Kim-Park, W.K.; Allam, E.S.; Palasuk, J.; Kowolik, M.; Park, K.K.; Windsor, L.J. Green tea catechin inhibits the activity and neutrophil release of Matrix Metalloproteinase-9. J. Tradit. Complement. Med. 2016, 6, 343-346. [CrossRef] [PubMed]

22. Ben Lagha, A.; Dudonné, S.; Desjardins, Y.; Grenier, D. Wild Blueberry (Vaccinium angustifolium Ait.) Polyphenols Target Fusobacterium nucleatum and the Host Inflammatory Response: Potential Innovative Molecules for Treating Periodontal Diseases. J. Agric. Food Chem. 2015, 63, 6999-7008. [CrossRef] [PubMed]

23. Lombardo Bedran, T.B.; Palomari Spolidorio, D.; Grenier, D. Green tea polyphenol epigallocatechin-3-gallate and cranberry proanthocyanidins act in synergy with cathelicidin (LL-37) to reduce the LPS-induced inflammatory response in a threedimensional co-culture model of gingival epithelial cells and fibroblasts. Arch. Oral Biol. 2015, 60, 845-853. [CrossRef] [PubMed]

24. Lombardo Bedran, T.B.; Morin, M.-P.; Palomari Spolidorio, D.; Grenier, D. Black Tea Extract and Its Theaflavin Derivatives Inhibit the Growth of Periodontopathogens and Modulate Interleukin-8 and $\beta$-Defensin Secretion in Oral Epithelial Cells. PLoS ONE 2015, 10, e0143158. [CrossRef] [PubMed]

25. Lombardo Bedran, T.B.; Feghali, K.; Zhao, L.; Palomari Spolidorio, D.M.; Grenier, D. Green tea extract and its major constituent, epigallocatechin-3-gallate, induce epithelial beta-defensin secretion and prevent beta-defensin degradation by Porphyromonas gingivalis. J. Periodontal Res. 2014, 49, 615-623. [CrossRef]

26. Tipton, D.A.; Carter, T.B.; Dabbous, M.K. Inhibition of interleukin $1 \beta$-stimulated interleukin- 6 production by cranberry components in human gingival epithelial cells: Effects on nuclear factor $\mathrm{kB}$ and activator protein 1 activation pathways. J. Periodontal Res. 2014, 49, 437-447. [CrossRef]

27. Tipton, D.A.; Cho, S.; Zacharia, N.; Dabbous, M.K. Inhibition of interleukin-17-stimulated interleukin-6 and -8 production by cranberry components in human gingival fibroblasts and epithelial cells. J. Periodontal Res. 2013, 48, 638-646. [CrossRef]

28. Tipton, D.A.; Babu, J.P.; Dabbous, M.K. Effects of cranberry components on human aggressive periodontitis gingival fibroblasts. J. Periodontal Res. 2013, 48, 433-442. [CrossRef]

29. Polak, D.; Naddaf, R.; Shapira, L.; Weiss, E.I.; Houri-Haddad, Y. Protective potential of non-dialyzable material fraction of cranberry juice on the virulence of $P$. gingivalis and F. nucleatum mixed infection. J. Periodontol. 2013, 84, 1019-1025. [CrossRef]

30. Hosokawa, Y.; Hosokawa, I.; Shindo, S.; Ozaki, K.; Matsuo, T. (-)-Epigallocatechin-3-gallate inhibits CC chemokine ligand 11 production in human gingival fibroblasts. Cell. Physiol. Biochem. 2013, 31, 960-967. [CrossRef]

31. Feldman, M.; Grenier, D. Cranberry proanthocyanidins act in synergy with licochalcone A to reduce Porphyromonas gingivalis growth and virulence properties, and to suppress cytokine secretion by macrophages. J. Appl. Microbiol. 2012, 113, 438-447. [CrossRef] [PubMed]

32. Tanabe, S.; Santos, J.; La, V.D.; Howell, A.B.; Grenier, D. A-type cranberry proanthocyanidins inhibit the RANKL-dependent differentiation and function of human osteoclasts. Molecules 2011, 16, 2365-2374. [CrossRef] [PubMed]

33. Löhr, G.; Beikler, T.; Podbielski, A.; Standar, K.; Redanz, S.; Hensel, A. Polyphenols from Myrothamnus flabellifolia Welw. inhibit in vitro adhesion of Porphyromonas gingivalis and exert anti-inflammatory cytoprotective effects in KB cells. J. Clin. Periodontol. 2011, 38, 457-469. [CrossRef]

34. Nakanishi, T.; Mukai, K.; Yumoto, H.; Hirao, K.; Hosokawa, Y.; Matsuo, T. Anti-inflammatory effect of catechin on cultured human dental pulp cells affected by bacteria-derived factors. Eur. J. Oral Sci. 2010, 118, 145-150. [CrossRef] [PubMed]

35. Hosokawa, Y.; Hosokawa, I.; Ozaki, K.; Nakanishi, T.; Nakae, H.; Matsuo, T. Catechins inhibit CXCL10 production from oncostatin M-stimulated human gingival fibroblasts. J. Nutr. Biochem. 2010, 21, 659-664. [CrossRef]

36. Hosokawa, Y.; Hosokawa, I.; Ozaki, K.; Nakanishi, T.; Nakae, H.; Matsuo, T. Tea polyphenols inhibit IL-6 production in tumor necrosis factor superfamily 14-stimulated human gingival fibroblasts. Mol. Nutr. Food Res. 2010, 54 (Suppl. 2), S151-S158. [CrossRef]

37. La, V.D.; Howell, A.B.; Grenier, D. Anti-Porphyromonas gingivalis and anti-inflammatory activities of A-type cranberry proanthocyanidins. Antimicrob. Agents Chemother. 2010, 54, 1778-1784. [CrossRef]

38. La, V.D.; Howell, A.B.; Grenier, D. Cranberry proanthocyanidins inhibit MMP production and activity. J. Dent. Res. 2009, 88, 627-632. [CrossRef]

39. Lee, Y.-L.; Hong, C.-Y.; Kok, S.-H.; Hou, K.-L.; Lin, Y.-T.; Chen, M.-H.; Wang, C.-C.; Lin, S.-K. An extract of green tea, epigallocatechin-3-gallate, reduces periapical lesions by inhibiting cysteine-rich 61 expression in osteoblasts. J. Endod. 2009, 35, 206-211. [CrossRef]

40. Inaba, H.; Tagashira, M.; Honma, D.; Kanda, T.; Kou, Y.; Ohtake, Y.; Amano, A. Identification of hop polyphenolic components which inhibit prostaglandin E2 production by gingival epithelial cells stimulated with periodontal pathogen. Biol. Pharm. Bull. 2008, 31, 527-530. [CrossRef]

41. Bodet, C.; Chandad, F.; Grenier, D. Inhibition of host extracellular matrix destructive enzyme production and activity by a high-molecular-weight cranberry fraction. J. Periodontal Res. 2007, 42, 159-168. [CrossRef] [PubMed]

42. Bodet, C.; Chandad, F.; Grenier, D. Cranberry components inhibit interleukin-6, interleukin-8, and prostaglandin E2 production by lipopolysaccharide-activated gingival fibroblasts. Eur. J. Oral Sci. 2007, 115, 64-70. [CrossRef] [PubMed]

43. Houde, V.; Grenier, D.; Chandad, F. Protective effects of grape seed proanthocyanidins against oxidative stress induced by lipopolysaccharides of periodontopathogens. J. Periodontol. 2006, 77, 1371-1379. [CrossRef] [PubMed]

44. Yun, J.H.; Pang, E.K.; Kim, C.S.; Yoo, Y.J.; Cho, K.S.; Chai, J.K.; Kim, C.K.; Choi, S.H. Inhibitory Effects of Green Tea Polyphenol (-)-Epigallocatechin Gallate on the Expression of Matrix metalloproteinase-9 and on the Formation of Osteoclasts. J. Periodontal Res. 2004, 39, 300-307. [CrossRef] [PubMed] 
45. Demeule, M.; Brossard, M.; Pagé, M.; Gingras, D.; Béliveau, R. Matrix metalloproteinase inhibition by green tea catechins. Biochim. Biophys. Acta 2000, 1478, 51-60. [CrossRef]

46. Makimura, M.; Hirasawa, M.; Kobayashi, K.; Indo, J.; Sakanaka, S.; Taguchi, T.; Otake, S. Inhibitory effect of tea catechins on collagenase activity. J. Periodontol. 1993, 64, 630-636. [CrossRef]

47. Chaudhary, L.R.; Avioli, L. V Regulation of interleukin-8 gene expression by interleukin-1beta, osteotropic hormones, and protein kinase inhibitors in normal human bone marrow stromal cells. J. Biol. Chem. 1996, 271, 16591-16596. [CrossRef]

48. Garlet, G.P. Critical reviews in oral biology \& medicine: Destructive and protective roles of cytokines in periodontitis: A re-appraisal from host defense and tissue destruction viewpoints. J. Dent. Res. 2010, 89, 1349-1363.

49. Delaleu, N.; Bickel, M. Interleukin-1 beta and interleukin-18: Regulation and activity in local inflammation. Periodontol. 2000 2004, 35, 42-52. [CrossRef]

50. Bloemen, V.; Schoenmaker, T.; de Vries, T.J.; Everts, V. IL-1 $\beta$ favors osteoclastogenesis via supporting human periodontal ligament fibroblasts. J. Cell. Biochem. 2011, 112, 1890-1897. [CrossRef]

51. Govindaraj, J.; Govindaraj, K.; Vidyarekha, U.; Padmavathy, K. Antiinflammatory effect of proanthocyanidins in experimental periodontitis in rats. Res. J. Pharm. Technol. 2019, 12, 4747-4751. [CrossRef]

52. Govindaraj, J.; Emmadi, P.; Deepalakshmi; Rajaram, V.; Prakash, G.; Puvanakrishnan, R. Protective effect of proanthocyanidins on endotoxin induced experimental periodontitis in rats. Indian J. Exp. Biol. 2010, 48, 133-142. [PubMed]

53. Toker, H.; Balci Yuce, H.; Lektemur Alpan, A.; Gevrek, F.; Elmastas, M. Morphometric and histopathological evaluation of the effect of grape seed proanthocyanidin on alveolar bone loss in experimental diabetes and periodontitis. J. Periodontal Res. 2018, 53, 478-486. [CrossRef] [PubMed]

54. Özden, F.O.; Sakallioğlu, E.E.; Sakallioğlu, U.; Ayas, B.; Erişgin, Z. Effects of grape seed extract on periodontal disease: An experimental study in rats. J. Appl. Oral Sci. 2017, 25, 121-129. [CrossRef] [PubMed]

55. Cai, Y.; Chen, Z.; Liu, H.; Xuan, Y.; Wang, X.; Luan, Q. Green tea epigallocatechin-3-gallate alleviates Porphyromonas gingivalisinduced periodontitis in mice. Int. Immunopharmacol. 2015, 29, 839-845. [CrossRef]

56. Cho, A.-R.; Kim, J.-H.; Lee, D.-E.; Lee, J.-S.; Jung, U.-W.; Bak, E.-J.; Yoo, Y.-J.; Chung, W.-G.; Choi, S.-H. The effect of orally administered epigallocatechin-3-gallate on ligature-induced periodontitis in rats. J. Periodontal Res. 2013, 48, 781-789. [CrossRef]

57. Kaboosaya, B.; Wulansari, L.K.; Trang Nguyen, V.N.; Kasugai, S. Drinking green tea alleviates alveolar bone resorption in ligature-induced periodontitis in mice. J. Oral Biosci. 2020, 62, 162-168. [CrossRef]

58. Isogai, H.; Isogai, E.; Takahashi, K.; Kurebayashi, Y. Effect of catechin diet on gingivitis in cats. Int. J. Appl. Res. Vet. Med. 2008, 6, $82-86$.

59. Díaz Sánchez, R.M.; Castillo-Dalí, G.; Fernández-Olavarría, A.; Mosquera-Pérez, R.; Delgado-Muñoz, J.M.; Gutiérrez-Pérez, J.L.; Torres-Lagares, D. A Prospective, Double-Blind, Randomized, Controlled Clinical Trial in the Gingivitis Prevention with an Oligomeric Proanthocyanidin Nutritional Supplement. Mediators Inflamm. 2017, 2017, 7460780. [CrossRef]

60. Chava, V.K.; Vedula, B.D. Thermo-reversible green tea catechin gel for local application in chronic periodontitis: A 4-week clinical trial. J. Periodontol. 2013, 84, 1290-1296. [CrossRef]

61. Hirsawa, M.; Takada, K.; Makimura, M.; Otake, S. Improvement of Periodontal Status by Green Tea Catechin Using a Local Delivery System: A Clinical Pilot Study. J. Periodontal Res. 2002, 37, 433-438. [CrossRef] [PubMed] 